\title{
Efficient Non-Viral Integration and Stable Gene Expression in Multipotent Adult Progenitor Cells
}

\author{
Andrew Wilber, ${ }^{1,2,3}$ Fernando Ulloa Montoya, ${ }^{4}$ Luke Hammer, ${ }^{4}$ \\ Branden S. Moriarity, ${ }^{1,2}$ Aron M. Geurts, ${ }^{1,2,5}$ David A. Largaespada, ${ }^{1,2}$ \\ Catherine M. Verfaillie, ${ }^{4,6}$ R. Scott McIvor, ${ }^{1,2}$ and Uma Lakshmipathy ${ }^{4,7}$ \\ ${ }^{1}$ Center for Genome Engineering, Gene Therapy Program, Institute of Human Genetics, University of Minnesota, \\ Minneapolis, MN 55455, USA \\ ${ }^{2}$ Department of Genetics, Cell Biology and Development, University of Minnesota, Minneapolis, MN 55455, USA \\ ${ }^{3}$ Department of Medical Microbiology, Immunology and Cell Biology and Simmons Cancer Institute, \\ Southern Illinois University School of Medicine, Springfield, IL 62702, USA \\ ${ }^{4}$ Department of Medicine, Stem Cell Institute, University of Minnesota, Minneapolis, MN 55455, USA \\ ${ }^{5}$ Department of Physiology, Human and Molecular Genetics Center, Medical College of Wisconsin, Milwaukee, WI 53226, USA \\ ${ }^{6}$ Interdepartmental Stem Cell Institute, Katholieke University Leuven, Leuven, Belgium \\ ${ }^{7}$ Life Technologies, 5781 Van Allen Way, Carlsbad, CA 92008, USA
}

Correspondence should be addressed to Uma Lakshmipathy, uma.lakshmipathy@lifetech.com

Received 14 January 2011; Revised 1 June 2011; Accepted 15 June 2011

Academic Editor: Mark G. Carter

Copyright ( 2011 Andrew Wilber et al. This is an open access article distributed under the Creative Commons Attribution License, which permits unrestricted use, distribution, and reproduction in any medium, provided the original work is properly cited.

\begin{abstract}
Non-viral integrating systems, PhiC31 phage integrase $(\phi \mathrm{C} 31)$, and Sleeping Beauty transposase (SB), provide an effective method for ex vivo gene delivery into cells. Here, we used a plasmid-encoding GFP and neomycin phosphotransferase along with recognition sequences for both $\phi \mathrm{C} 31$ and $\mathrm{SB}$ integrating systems to demonstrate that both systems effectively mediated integration in cultured human fibroblasts and in rat multipotent adult progenitor cells (rMAPC). Southern blot analysis of G418-resistant rMAPC clones showed a 2-fold higher number of SB-mediated insertions per clone compared to $\phi$ C 31. Sequence identification of chromosomal junction sites indicated a random profile for SB-mediated integrants and a more restricted profile for $\phi \mathrm{C} 31$ integrants. Transgenic rMAPC generated with both systems maintained their ability to differentiate into liver and endothelium albeit with marked attenuation of GFP expression. We conclude that both SB and $\phi \mathrm{C} 31$ are effective non-viral integrating systems for genetic engineering of MAPC in basic studies of stem cell biology.
\end{abstract}

\section{Introduction}

Stem cells are capable of long-term self-renewal in culture and can be induced to form a variety of cell types. These characteristics provide a unique resource for genetic and developmental studies or for therapeutic use in the development of cell and gene therapies. Multipotent adult progenitor cells (MAPC) represent a class of stem cells derived from bone marrow (BM) and other adult mammalian tissues that can be expanded in culture [1-3] to generate multiple cell types in vitro and in vivo [4-8]. Several transplantation studies have demonstrated that human MAPCs are beneficial for functional recovery following vascular ischemia possibly via trophic effects [9-12] and possess contact-independent immunosuppressive potential $[13,14]$. These properties suggest that MAPCs may be an effective source for potential use in immunomodulation and in the treatment of ischemic diseases. Further extension of its use in single-gene disorders and for use in creation of cell-based screening models requires methods to engineer MAPC by introduction of defined genetic elements.

Non-viral DNA-mediated gene transfer has been explored as a means of expressing new genes in a variety of different cell types in vitro and in vivo. However, the usefulness of naked DNA vectors is often restricted by the inability to provide sustained gene expression. Stable integration of 
the plasmid-encoded sequence is inefficient, as it relies on random double-strand break-mediated recombination. One method of addressing this problem is to use non-viral vectors in conjunction with a recombinase that has the capability of integrating genetic cargo into cellular chromosomes.

Sleeping Beauty (SB) transposase and PhiC31 ( $\phi \mathrm{C} 31)$ integrase are plasmid-based systems that have been demonstrated to mediate stable gene transfer and expression in mammalian cells. SB is a member of the Tc1/mariner-like family of DNA transposons, which are found as inactive remnants throughout various genomes in all of the major kingdoms except bacteria and mediate gene transfer by a "cut-and-paste" mechanism [15] (Figure 1). The SB transposon system was generated by "repairing" an evolutionarily decayed $T c 1$-like sequence found in the genomes of salmonid fish [16]. The autonomous element consists of the catalytic transposase flanked by inverted terminal repeats (ITRs) each containing two direct repeats (DR), which are binding sites for the transposase and essential for transposition $[16,17]$. For gene transfer applications, the transposase is separated from the transposon ends and replaced with any DNA cargo. The transposase can be supplied on the same (cis) or separate (trans) plasmid from the one encoding the transposon or as in vitro transcribed mRNA [18]. When expressed, the transposase excises the transposon from the donor plasmid and precisely inserts this genetic element into vertebrate chromosomes at a TA dinucleotide. In contrast to random recombination, insertion mediated by transposition occurs without altering the flanking chromosomal sequence. The SB transposon system has been used for stable genetic modification of multiple rodent and human cell lines [16, $17,19]$ and primary cells including mouse liver [20-25], human skin cells [26], mouse lung [27-29], and human peripheral blood T-cells [30] as well as embryonic stem (ES) cells derived from mice $[31,32]$ and humans $[33,34]$. Murine MAPC modified using an SB transposon engineered for expression of a dual reporter encoding DsRed2 and firefly luciferase have been used to study the homing pattern of MAPC via in vivo bioluminescence imaging after transplant into immunodeficient mice [35]. Furthermore, recent studies have demonstrated the usefulness of the SB transposon system for genetic modification of human CD $34^{+}$ hematopoietic progenitor cells isolated from cord blood [36, 37].

The $\phi \mathrm{C} 31$ integrase is a member of the serine recombinase family found in Streptomyces [38]. Under natural conditions, the two-component $\phi \mathrm{C} 31$ system mediates a unidirectional recombination event between the attP site of the phage genome and the attB site of the Streptomyces chromosome. For applications in mammalian cells, gene sequences on an attB containing plasmid are inserted into cellular chromosomes at sites having partial homology to the wild-type phage attP sequence ("pseudo-attP" sites) when codelivered with a source of the phage integrase enzyme $[39,40]$ (Figure 1). The frequency of PhiC31-mediated integration is about 10- to 100-fold higher when compared to the reversible recombinases (Cre and FLP) both of which require that the target recognition sequence be preinserted into the genome [41]. The utility of the $\phi \mathrm{C} 31$ system for mediating stable gene expression has been demonstrated in various cultured mammalian cell lines [42], and in primary cells, including mouse liver [43, 44], human skin cells [45], and muscle-derived stem cells [46] as well as for site-specific genomic insertion in mouse [47] and human ES cells [48].

Here, we directly tested these two non-viral integrating vector systems for the capacity to mediate stable gene transfer into primitive adult stem cells. An internally controlled, bifunctional plasmid was utilized to codeliver recognition sequences for both $\phi \mathrm{C} 31$ and SB integrating systems. We investigated the frequency of gene insertion, strength of gene expression, and the effect of genetic modification on the stem cell potential of MAPC. These results provide an assessment of the relative usefulness of these non-viral integrating systems for the purpose of ex vivo gene transfer and a means to generate integrated engineering platforms for non-viral delivery and expression of transgenes in stem cells.

\section{Materials and Methods}

2.1. Plasmid Construction. The integrating vector (pKT2/ NAG) was constructed using T2 inverted terminal repeat sequences flanking the cargo [49]. For construction of pKT2/NAG, the neomycin phosphotransferase (Neo) cDNA was obtained by PCR using pT/Neo [50] as a template with primers Neo-F (5'-GCC ACC ATG ATT GAA CAA GAT GGA TTG C-3') and Neo-R (5'-CGC TCA GAA GAA CTC GTC AAG AAG-3'), and subsequently cloned into pCR2.1-TOPO (Invitrogen, Carlsbad, Calif, USA) to form pTOPO-Neo. An EcoRI fragment containing the amplified Neo sequence was inserted into the polylinker between the PGK promoter and rabbit $\beta$-globin polyadenylation signal of pKT2/PGK to form pKT2/PGK-Neo. The attB sequence and EF1 $\alpha$ regulated GFP coding sequence was created by introducing a 307-bp EcoR1 fragment containing the $\phi \mathrm{C} 31$ attB site from pTA-attB [39], kindly provided by Dr. Michele Calos, Stanford University) into the same site in plasmid pVITRO-GFP (Invivogen, San Diego, Calif, USA). A HindIII-XhoI fragment containing the attB sequence, EF1 $\alpha$ promoter, GFP coding sequence, and SV40 polyadenylation signal was subsequently isolated and cloned upstream of the PGK promoter in pKT2/PGK-Neo between HindIII and SalI.

The luciferase (pCMV-Luc) and SB10 transposase (pCMV-SB) expression vectors have been previously described $[50,51] . \phi \mathrm{C} 31$ integrase was placed under transcriptional control of the CMV promoter by isolating a NheISpeI fragment containing the integrase coding sequence from pTOPO-Int (kindly provided by Dr. Michele Calos, Stanford University) and cloning it in place of luciferase in pCMV-Luc between NheI and XbaI. Plasmid DNA was prepared using an Endofree Maxi Prep Kit (Qiagen, Valencia, Calif, USA).

2.2. Cell Culture and Gene Transfer. Human fibrosarcoma HT1080 cells were maintained in complete growth medium consisting of Dulbecco's modified Eagle medium supplemented with $10 \%$ fetal bovine serum and $1 \%$ antimycoticantibiotic (Invitrogen, Carlsbad, Calif, USA), and incubated at $37^{\circ} \mathrm{C}$ in a humidified atmosphere containing $5 \% \mathrm{CO}_{2}$. 


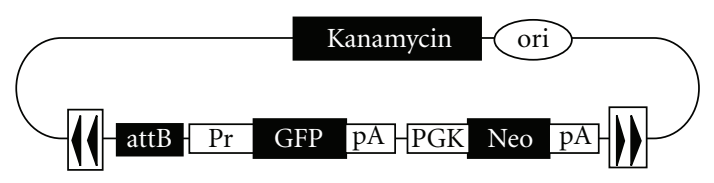

(a)

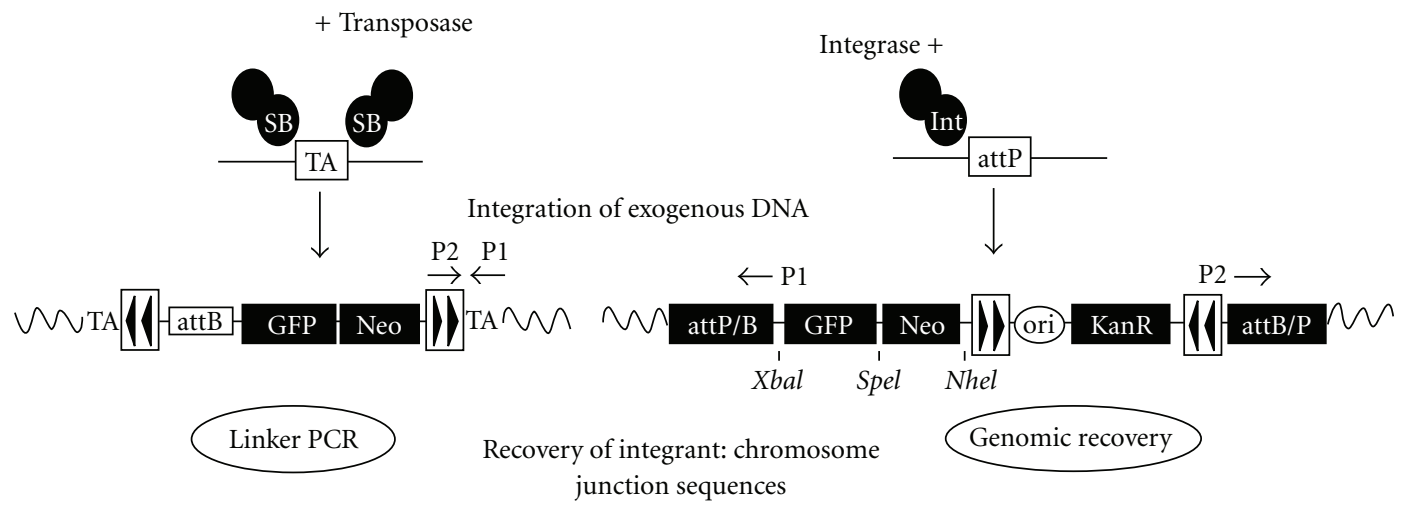

(b)

FIGURE 1: Schematic diagram of the internally controlled pKT2/NAG vector and integration products mediated by Sleeping Beauty (SB) transposase and by bacteriophage PhiC31 ( $\phi \mathrm{C} 31)$ integrase. (a) The integrating vector consists of (i) a $\phi \mathrm{C} 31$ integrase recognition site (attB); (ii) eF1 $\alpha$ or CMV- (Pr-) regulated GFP expression unit; (iii) neomycin resistance gene (Neo) transcriptionally regulated by the PGK promoter; (iv) flanking T2 transposase binding sites (IR/DRs; boxes with double triangles) separated by; (v) a colE1 bacterial origin of replication and kanamycin resistance gene; (vi) pA, polyadenylation signal from the rabbit beta globin gene. (b) SB transposase-mediated integration (left): the SB transposase excises transposon sequences at IR/DR transposase binding sites and precisely inserts them into TAdinucleotide targets in cellular chromosomes, which are subsequently duplicated. $\phi \mathrm{C} 31$ integrase-mediated integration (right): exogenous gene sequences on an attB containing plasmid integrate into mammalian genomes at "pseudo-attP" sites, chromosomal sequences having partial homology to the wild-type phage attP sequence.

The day before transfection, $4-5 \times 10^{5}$ cells were seeded into $6-\mathrm{cm}$ tissue culture plates. Cells were cotransfected with pKT2/NAG (500 ng) plus pCMV-Luc, pCMV-SB, or pCMV-Int (150, 500, or $1500 \mathrm{ng})$ using SuperFect reagent (Qiagen, Valencia, Calif, USA) in a final volume of $1 \mathrm{~mL}$ complete growth medium for three hours before changing the medium. For stable gene transfer, cells were collected two days after transfection, stained with trypan blue, and counted. Viable cells $(30,000)$ were plated into $100-\mathrm{mm}$ dishes containing complete growth medium supplemented with $850 \mu \mathrm{g} / \mathrm{mL}$ G418 (Invitrogen, Carlsbad, Calif, USA). After 14 days of selection, cells were fixed and stained with a $70 \%$ methanol solution containing $1 \%$ crystal violet.

Rat MAPC (rMAPC) were maintained on fibronectin coated flasks or dishes using previously described conditions [52]. On the day of transfection, rMAPC were released from plates with trypsin, washed with PBS, and 0.1 to $0.5 \times$ $10^{6}$ viable cells (trypan blue negative) were resuspended in nucleofection solution V (Amaxa, Gaithersburg, Md, USA) with pKT2/NAG $(5 \mu \mathrm{g})$ and an equal amount of either pCMV-Luc, pCMV-SB, or pCMV-Int, transferred into the supplied cuvette, and electroporated (Amaxa; setting A-23) as described earlier $[52,53]$. The cells were immediately resuspended in prewarmed growth medium and seeded into $6 \mathrm{~cm}$ plates. For stable transfection, cells were grown in medium supplemented with $\mathrm{G} 418(400 \mu \mathrm{g} / \mathrm{mL}) 1$ day after transfection.
2.3. Flow Cytometry. HT1080 cells or MAPC were harvested and rendered into single-cell suspensions for flow cytometric analysis. Live cells were identified and gated by exclusion of propidium iodide and then tested for expression of GFP on a FACSCalibur System (Beckton-Dickinson) using CellQuest analysis software (BD Biosciences, Heidelberg, Germany).

2.4. Southern Hybridization Analysis. Southern blotting was performed as previously described [44]. Briefly, $10 \mu \mathrm{g}$ of genomic DNA isolated from several G418-resistant MAPC clones was digested overnight with BamHI (SB-treated cells) or SpeI ( $\phi$ C31-treated cells), electrophoresed through $0.8 \%$ agarose gel, and then blotted onto nytran. An 835-bp fragment encoding the GFP sequence was isolated from the integrating vector (pKT2/NAG) by AgeI-HindIII digest and ${ }^{32} \mathrm{P}$ radio-labeled using the Prime-It II Random Primer Labeling Kit (Stratagene, La Jolla, Calif, USA) to use as the DNA probe.

2.5. In Vitro Differentiation and Marker Expression. Undifferentiated rMAPC that were unmanipulated, had gone through random integration upon cotransfection with the luciferase expression vector or stable integration mediated by $\phi \mathrm{C} 31$ integrase or SB transposase were harvested for RNA isolation and RT-PCR analysis was carried out as previously described [52]. The rMAPC were differentiated 
into endothelium or hepatocytes as described $[2,6,7]$. For endothelial differentiation, transgenic MAPC were cultured in basal growth medium supplemented with $2 \%$ or $5 \%$ serum plus vascular endothelial growth factor (VEGF, $10 \mathrm{ng} / \mathrm{mL}$ ). Liver differentiation was elicited by addition of $2 \%$ serum, hepatocyte growth factor (HGF, $20 \mathrm{ng} / \mathrm{mL}$ ), and fibroblast growth factor-4 (FGF4, $10 \mathrm{ng} / \mathrm{mL}$ ) to the growth medium. At days 9 and 14, cells were harvested for RNA isolation, and end-stage RT-PCR or qRT-PCR analysis was performed using primers for endothelium-specific transcripts vascular endothelial growth factor receptor-2 (Flk1), vascular endothelial growth factor receptor-1 (Flt1), and endothelialderived gene-1 (Eg1) or hepatocyte-specific markers hepatocyte nuclear factor-3-beta (HNF3b), alpha-fetoprotein (AFP), and transthyretin (Ttr), where glyceraldehyde-3phosphate dehydrogenase (GAPDH) served as an internal control for RNA loading and integrity. Amplicons from endstage RT-PCR were separated by electrophoresis through $2 \%$ agarose gel. For qRT-PCR, target gene expression was normalized to GAPDH and relative expression calculated by the $2^{-\Delta \Delta C T}$ formula. Primer sequences described in earlier studies were used $[6,7]$. All experiments were performed at least in duplicate with technical replicates in each set.

2.6. Cytogenetic Analysis. Transgenic rMAPC were washed to remove dead cells and resuspended in $10 \mathrm{~mL}$ culture medium. Cells were sent to the University of Minnesota Cytogenetics Core Laboratory for analysis. Briefly, cells were treated with colcemid for 3 hours and then harvested according to standard cytogenetic protocol. Approximately 100 metaphases were evaluated by G-banding at a 400-425 band level resolution.

2.7. Recovery of Integration Sites. G418-resistant clones were isolated after cotransfection of each cell type with pKT2/NAG plus pCMV-Luc, pCMV-SB, or pCMV-Int. Genomic DNA (gDNA) was isolated using the Puregene DNA purification kit (Gentra Systems, Minneapolis, Minn, USA). A genomic recovery method was used for identification of PhiC31 integrase-mediated chromosomal insertions. High molecular weight DNA $(2 \mu \mathrm{g})$ was digested with NheI, SpeI, and XbaI (which generate compatible 5' termini; schematically represented in Figure 1) precipitated in $100 \%$ ethanol and the recovered DNA was ligated under dilute conditions $(500 \mu \mathrm{L})$ with 4 units of T4 DNA ligase (New England BioLabs, Beverly, Mass, USA). The ligated DNA was precipitated with $100 \%$ isopropanol, pelleted by microcentrifugation and washed with $70 \%$ ethanol before being resuspended in $10 \mu \mathrm{L}$ of sterile $\mathrm{H}_{2} \mathrm{O}$. Two microliters of this DNA was electroporated into DH10B electrocompetent E. coli (Promega, Madison, Wis, USA), allowing bacterial cells to recover in SOC media by incubation with agitation at $37^{\circ} \mathrm{C} / 200 \mathrm{rpm}$ for 1 hour before plating on Luria/Bertania agar containing $50 \mu \mathrm{g} / \mathrm{mL}$ kanamycin. Plasmid DNA was isolated and sequenced using primers that flank the attB site (shown in Figure 1(b)): attB-F (5'-TAG GGC GAA AGG AAG GG TGG-3') and $a t t B-R\left(5^{\prime}\right.$-GGC TTC GAG ACC GTG ACC TA-3'). For SB-mediated integration events, a linker-mediated PCR technique was used to recover transposon-chromosome junction sequences as described [54] and schematically represented in Figure 1. Genomic DNA $(2 \mu \mathrm{g})$ was digested with $B f a I$ and ligated to a linker. Primary PCR was performed with primers $5^{\prime}$-GTA ATA CGA CTC ACT ATA GGG C-3' and 5'-CTG GAA TTT TCC AAG CTG TTT AAA GGC ACA GTC AAC-3' under the following conditions: $94^{\circ} \mathrm{C}$ for $2 \mathrm{~min}$, then 25 cycles of $94^{\circ} \mathrm{C}$ for $15 \mathrm{sec}, 60^{\circ} \mathrm{C}$ for $30 \mathrm{sec}$ and $72^{\circ} \mathrm{C}$ for $90 \mathrm{sec}$. The PCR products were diluted and nested PCR was carried out under the same conditions using primers $5^{\prime}$-AGG GCT CCG CTT AAG GGA C-3' and 5'-GAC TTG TGT CAT GCA CAA AGT AGA TGT CC-3'. The products of the nested reaction were separated by electrophoresis through $2 \%$ agarose gel. Specific products were excised, purified using the Qiaquick gel extraction kit (Qiagen, Valencia, Calif, USA), and cloned into pGEM-T vector (Promega, Madison, Wis, USA) using ElectroMax DH10B (Invitrogen, Carlsbad, Calif, USA) for transformation. All recovered integration events were sequenced at the Advanced Genetics Analysis Center at the University of Minnesota and subjected to BlastN analysis against the rat genome using the ENSEMBL database.

\section{Results}

3.1. Gene Transfer and Stable Expression in Cultured Human Fibroblasts. The SB and $\phi \mathrm{C} 31$ recombinases each require their own unique recognition sequence and catalytic component to mediate the insertion of gene sequences into chromosomes. We directly compared the effectiveness of integration and long-term expression using a single twocomponent plasmid that is internally controlled for the integrating sequence (Figure 1(a)). The mode of integration into the host genome catalyzed by $\mathrm{SB}$ and $\phi \mathrm{C} 31$ is represented in Figure 1(b).

To functionally test our internally controlled vector (pKT2/NAG) when cotransfected with each recombinase, we performed a colony-forming assay in cultured human male fibrosarcoma HT1080 cells. This cell line was selected on the basis of a relatively normal karyotype by cytogenetic analysis (46, XY, with 5p+ and 11q+) [55]. The effect of the dose of the codelivered recombinase-encoding plasmid on stable gene transfer and expression was determined by G418-resistant colony formation and GFP fluorescence. pKT2/NAG (500 ng) was cotransfected in triplicate with 150, 500 , or $1500 \mathrm{ng}$ of either CMV-regulated luciferase (pCMVLuc), transposase (pCMV-SB), or integrase (pCMV-Int) expression plasmids (Figure 2(a)). Flow cytometric analysis of GFP expression two days later demonstrated nearly equivalent transfection efficiencies $(20 \%-25 \%$ of cells were GFP positive; data not shown). Similar to previous studies $[20,50,56]$, our data revealed the inhibitory effect that is frequently observed with increasing doses of transposaseencoding plasmid. The lowest dose of pCMV-SB10 (150 ng) yielded the greatest increase (20-fold greater than the no transposase control) in G418-resistant colony formation, while the highest dose (1500 ng) produced only 5-fold more colonies than the no transposase control (Figure 2(b)). For 


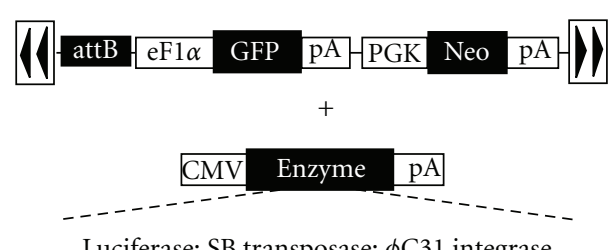

(a)

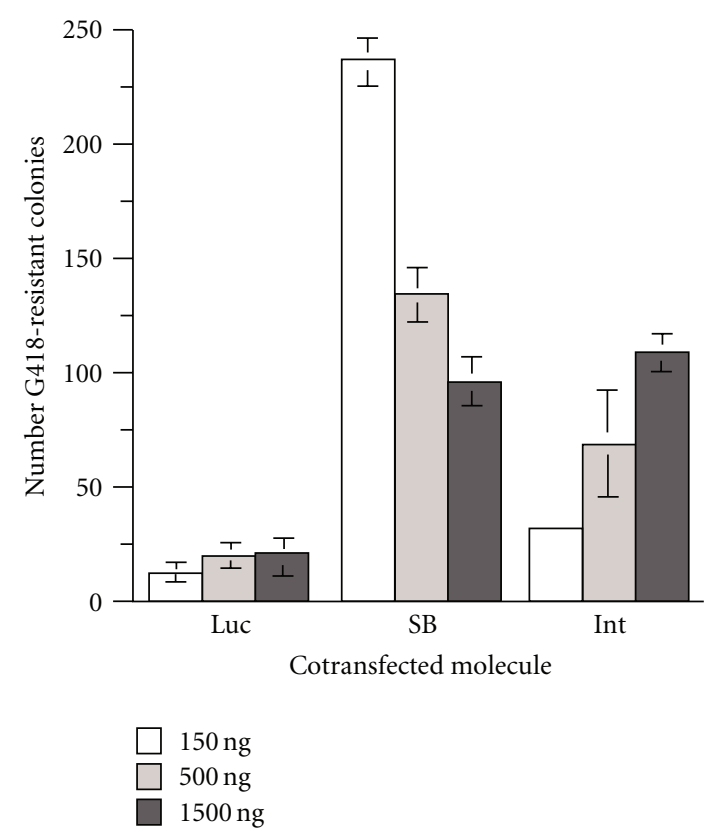

(b)
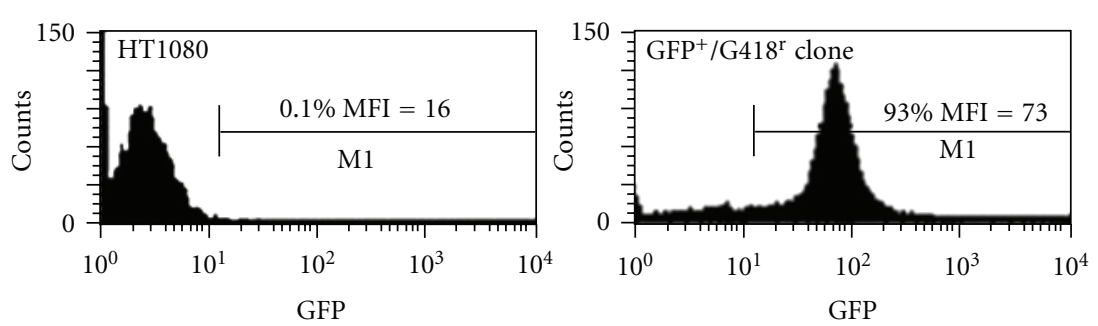

(c)

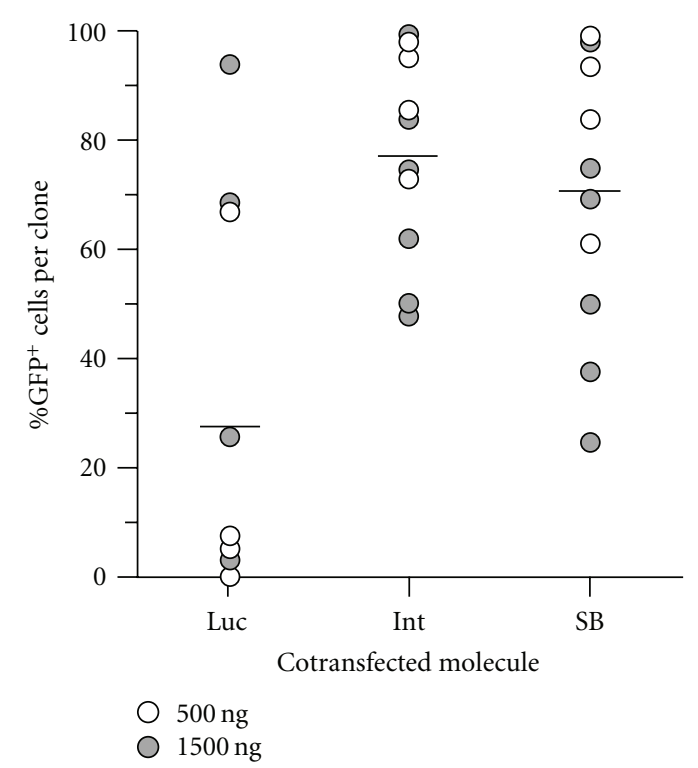

(d)

FIGURE 2: Stable expression mediated by $S B$ transposase and $\phi$ C31integrase in cultured human fibroblasts. (a) Schematic diagram of plasmids cotransfected into HT1080 cells in a colony-forming assay. The integrating vector (pKT2/NAG) is described in Figure 1. Recombinaseencoding plasmids are transcriptionally regulated by the cytomegalovirus immediate early promoter (CMV). The firefly luciferase encoding expression vector (Luc) serves as a control for colony formation resulting from random recombination compared to stable gene transfer mediated by SB transposase (SB) or $\phi \mathrm{C} 31$ integrase (Int). (b) Colony-forming assay for integration efficiency. HT1080 cells $\left(4-5 \times 10^{5}\right)$ were cotransfected in triplicate with pKT2/NAG (500 ng) and $150 \mathrm{ng}, 500 \mathrm{ng}$, or $1500 \mathrm{ng}$ of Luc, SB, or Int encoding expression plasmids as described in Section 2. The number of G418-resistant colonies per $3 \times 10^{4}$ cells plated is shown for each group $(n=3)$. Values are reported as mean \pm SE. (c) GFP expression in transgenic HT1080 cells. Examples of flow cytometry plots are shown for unmanipulated HT1080 cells (left panel; GFP negative) or an expanded G418-resistant clone (right panel; GFP positive). (d) Percentage GFP-positive cells determined by flow cytometric analysis of 10 independent G418-resistant clones expanded from HT1080 cells cotransfected with pKT2/NAG and 500 ng (open circle) or $1500 \mathrm{ng}$ (filled circle) of Luc, SB, or Int expression vectors. Mean percentages of GFP-positive cells for each condition are indicated by solid lines.

$\phi \mathrm{C} 31$ integrase, increasing the concentration of pCMVInt improved G418-resistant colony formation (from 3- to 7 -fold) compared to the no integrase control pKT2/NAG (Figure 2(b)).

Ten G418-resistant clones generated by cotransfection with $500 \mathrm{ng}$ or $1500 \mathrm{ng}$ of SB transposase or $\phi \mathrm{C} 31$ integrase were independently expanded in G418-containing medium for an additional four weeks to characterize expression of the upstream GFP reporter by flow cytometry (Figures 2(c) and $2(\mathrm{~d}))$. Three drug-resistant clones generated by random recombination (+ pCMV-Luc) showed expression of GFP (> $60 \%)$, but the majority failed to express GFP $(6 / 10<10 \%$
GFP positive). In contrast, GFP expression was maintained in all clones rendered drug-resistant by SB- or PhiC31mediated integration but with increased efficiency in cells transfected with $500 \mathrm{ng}$ versus $1500 \mathrm{ng}$ of each recombinase. These results indicate that the single bifunctional construct in the presence of the appropriate recombinase can mediate integration into the host genome resulting in persistent transgene expression.

3.2. Non-Viral Integration Efficiency and Stable Gene Expression in MAPC. Bone marrow-derived stem cells with the capacity for self-renewal and proliferation in culture are 

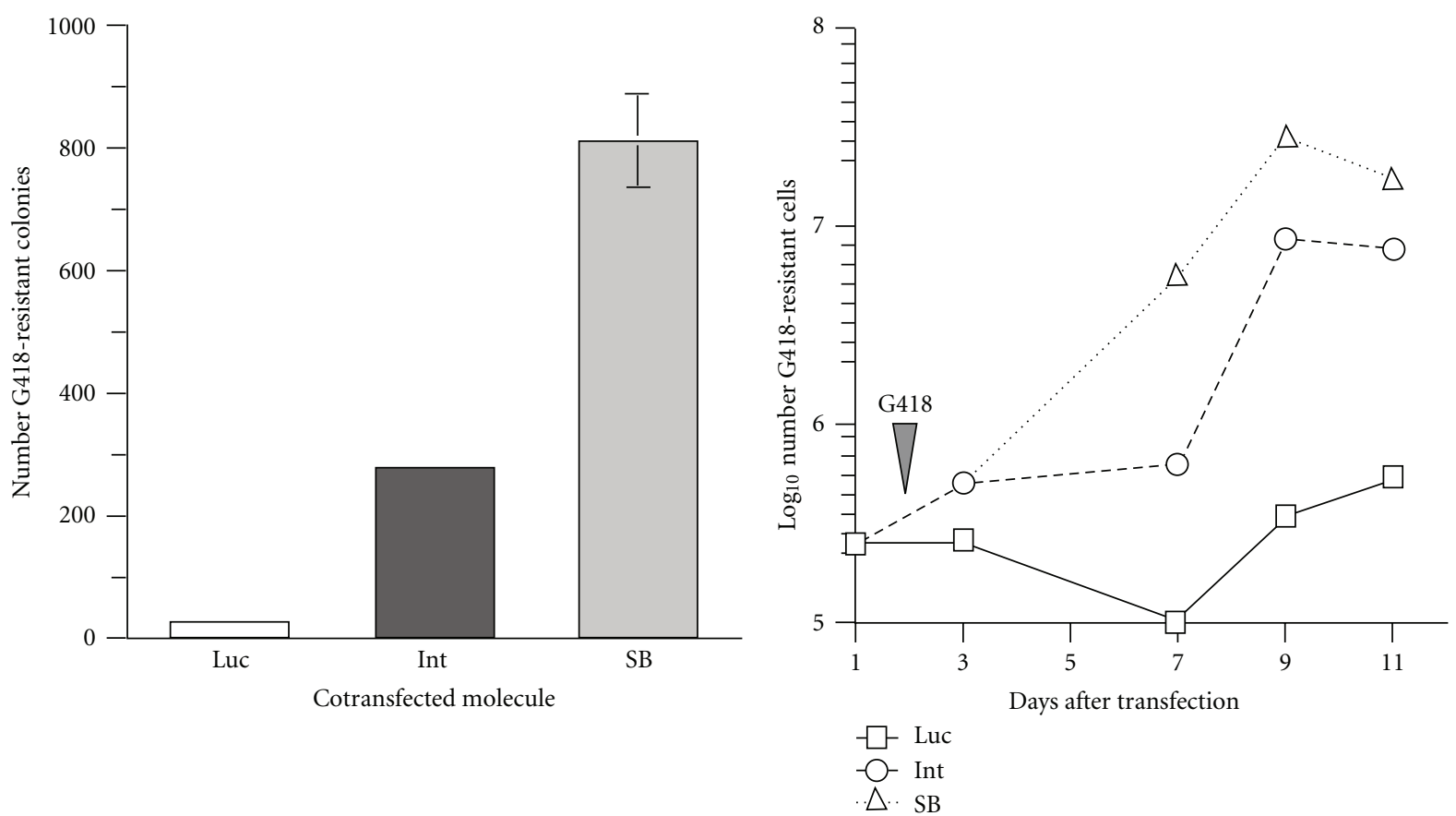

(a)

SB

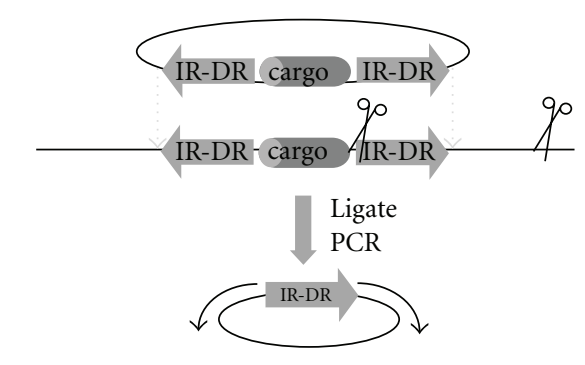

cargo caactg TATAGGGATCTGGTACCA
caactg TActct tgtgataat t g
caactg TAcatactacgt tagtg c
Position $12 \mathrm{p} 12$ $5 \mathrm{q} 11$ (b)

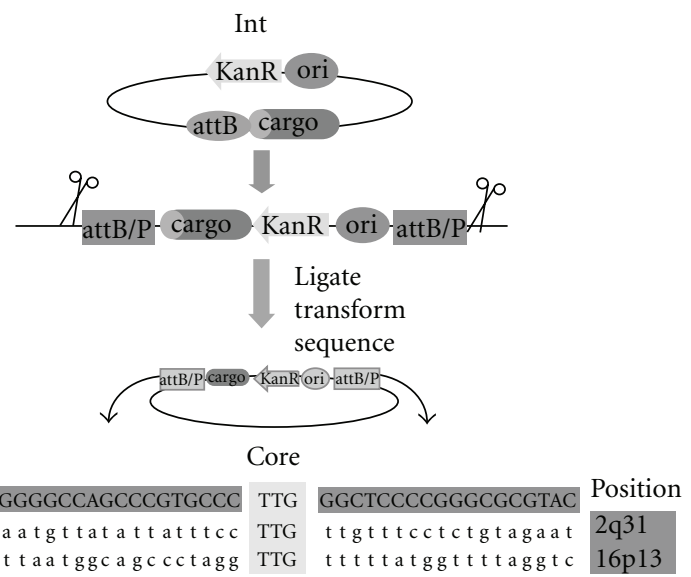

(c)

FIgURE 3: Non-viral integration efficiency in MAPC. Nucleofected rMAPC were plated and the medium was supplemented with G418 $(400 \mu \mathrm{g} / \mathrm{mL})$ one day later. (a) Colony-forming assay. After 10-12 days of growth under selective conditions, cells were fixed and stained to determine the frequency of G418-resistant colony formation. The number of G418-resistant colonies $(n=3)$ for each group is shown \pm S.D. (b) Cells were harvested into a suspension and viable cell counts were performed by trypan blue exclusion on the indicated days and the total number of cells in culture is reported as mean \pm SE. (c) Genomic DNA isolated from the individual clones obtained with SB and Int was subjected to restriction enzyme digestion, plasmid sequence rescue, and sequencing of the recovered fragment carried out to determine the genomic site of integration.

important biological tools for studying cell fate and differentiation. To determine the integration efficiency mediated by $\mathrm{SB}$ transposase (SB) and $\phi \mathrm{C} 31$ integrase (Int) in adult stem cells, we evaluated stable gene transfer in MAPC derived from the bone marrow of newborn rat (postnatal days 2-5). Nucleofection was used as the method of gene transfer based on previous studies demonstrating efficient gene transfer and low toxicity in these cells $[52,53]$.
The integrating vector pKT2/NAG was codelivered with a source of recombinase at a $1: 1$ mass ratio (a dose demonstrated to effectively render HT1080 cells resistant to G418 selection) into undifferentiated MAPC using Amaxa Nucleofector technology (described in Section 2.2), where transfection efficiency ranged from $15 \%$ to $20 \%$ by flow cytometric analysis of GFP positive cells 24 hours later (data not shown). After 7 to 10 days of growth in culture, we found 


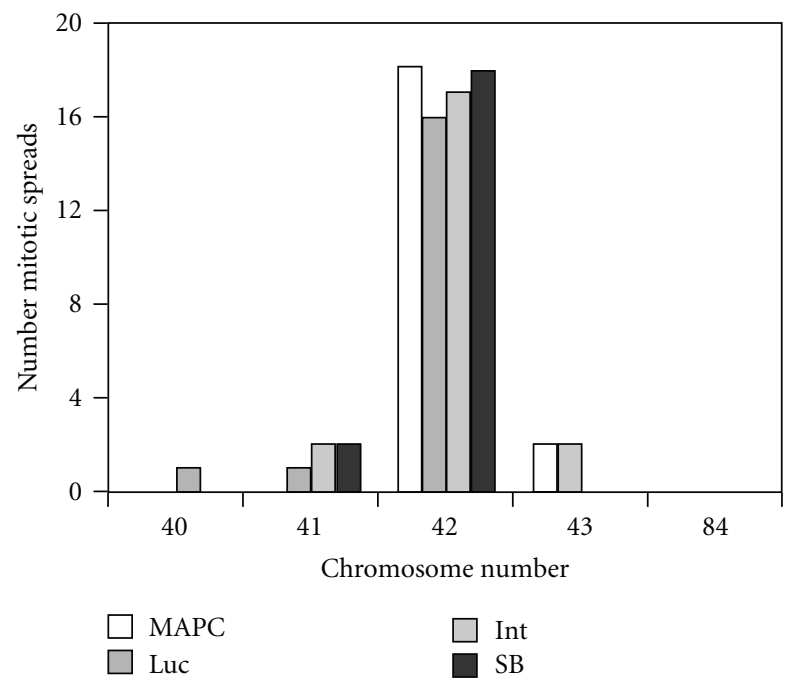

(a)
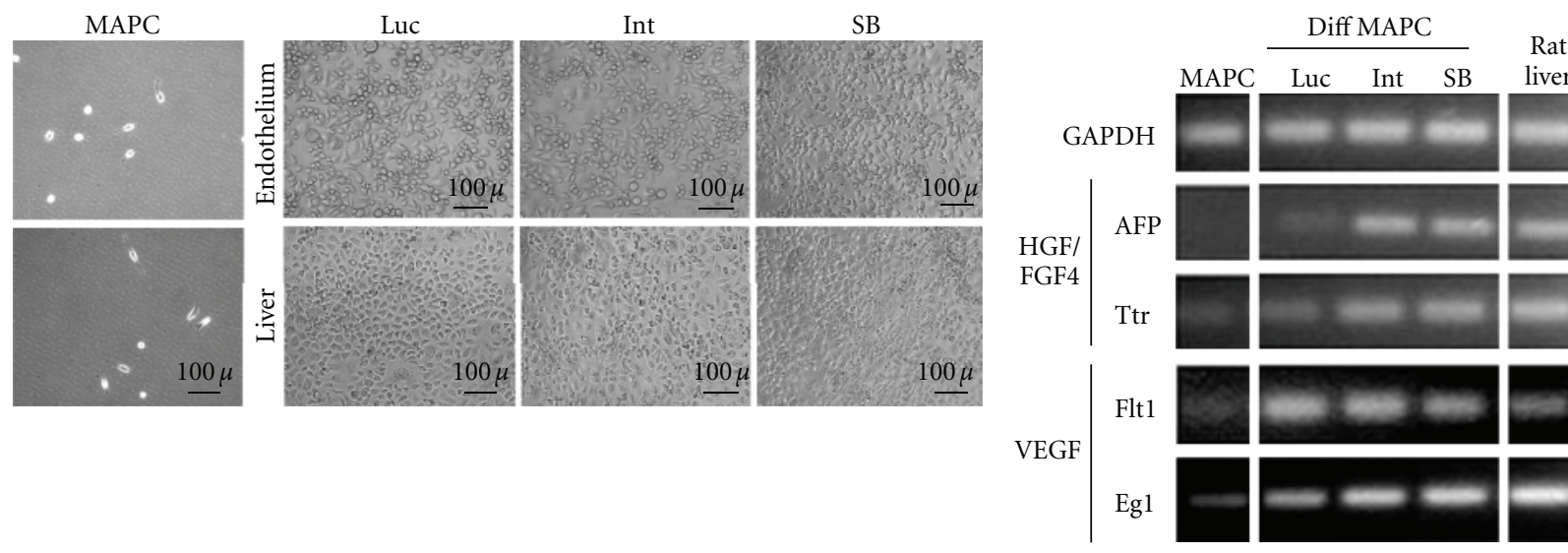

(b)

(c)

FIGURE 4: MAPC maintain their stem-cell character and the ability to differentiate following genetic engineering. (a) Karyotypic analysis of pooled G418-resistant cells; the number of mitotic spreads containing the number of chromosomes indicated on the abscissa is indicated. Absence of aneuploid or diploid cells indicates no gross karyotypic anomalies or aberrant cell-cycle activity in the analyzed cells. (b) MAPCs are small spindle-shaped cells that are cultured at very low density. Morphological changes following differentiation into liver and endothelium for two weeks as described in Section 2 show significant difference between cells LUC-, Int- or SB-treated cells. (c) RT-PCR analysis of the differentiated cells shows the presence of alpha-fetoprotein (AFP) and transthyretin (TTR) for liver differentiation, and vascular endothelial growth factor receptor-1 (Flt1) and endothelial-derived gene-1 (Eg1) for differentiation into endothelium. Rat liver was used as a positive control for liver and endothelial markers and undifferentiated MAPC used as the negative control.

that G418-resistance was increased over background by 30fold for SB and 10-fold for Int when MAPC were allowed to form distinct colonies (Figure 3(a)) or when pooled drug resistant clones were subcultured to maintain the cell density between 100-500 cells $/ \mathrm{cm}^{2}$ (Figure 3(b)). These clones were expanded for further analysis including determination of genomic integration site (Figure 3(c)).

\subsection{Transgenic MAPC Maintain the Ability to Differentiate.} The effect of genetic engineering on the karyotype of MAPC was evaluated at the cytogenetic level for G418-resistant pooled clones that were maintained at a density of 100 500 cells $/ \mathrm{cm}^{2}$. The majority of the spreads $(>80 \%)$ were diploid with a normal karyotype for unmanipulated rat cells as well as cells that had gone through random integration upon cotransfection with the luciferase expression vector or stable integration mediated by $\phi \mathrm{C} 31$ integrase or $\mathrm{SB}$ transposase (Figure 4(a)).

MAPC are characterized by the capacity to differentiate into multiple cells types. Cells engineered for G418resistance using the control Luc, SB transposase, or PhiC31 integrase were maintained in culture under reduced serum $(2-5 \%)$ and in the presence of vascular endothelial growth factor (VEGF) or fibroblast growth factor 4 (FGF4) plus hepatocyte growth factor (HGF). Following 14 days of differentiation, distinct changes in the morphology of spindleshaped MAPC were observed. No significant difference in the morphology between Luc, SB, and Int was apparent 


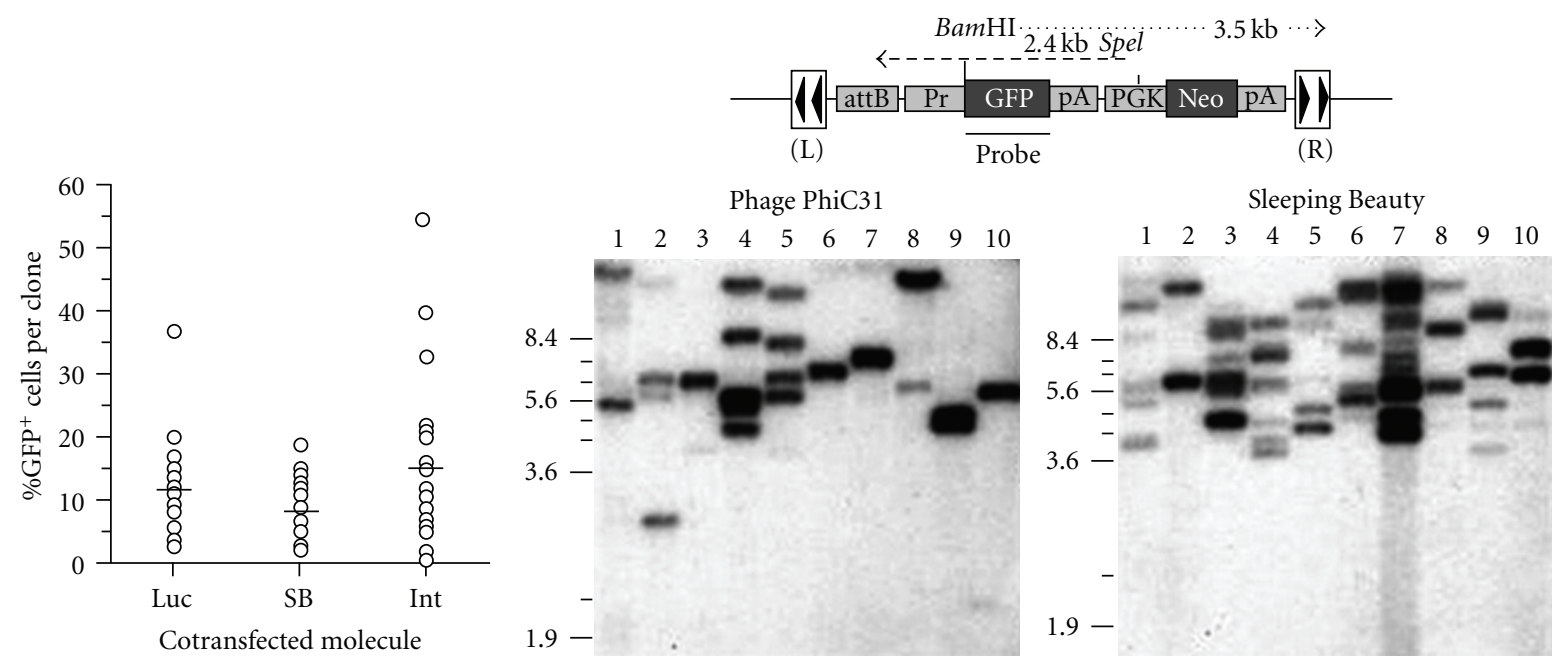

(a)
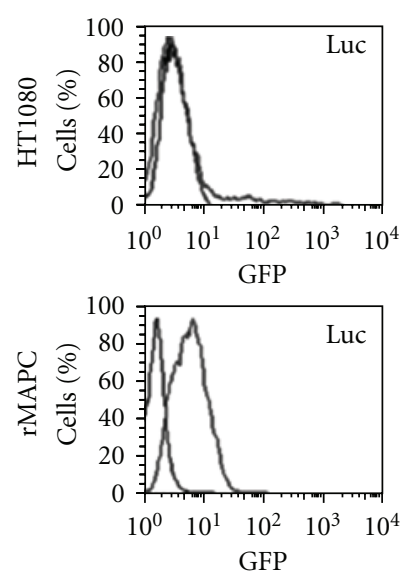
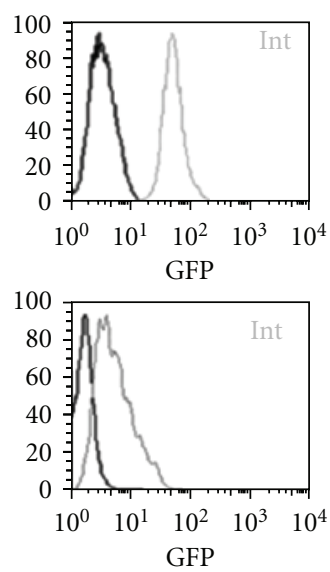

(c)
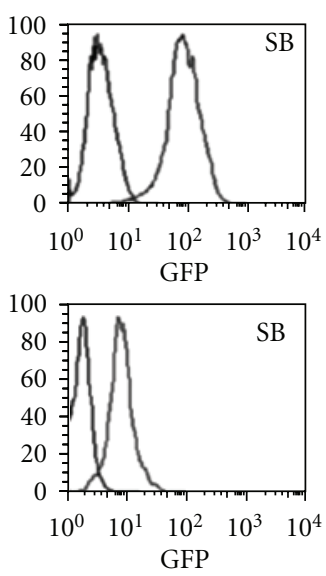

(b)

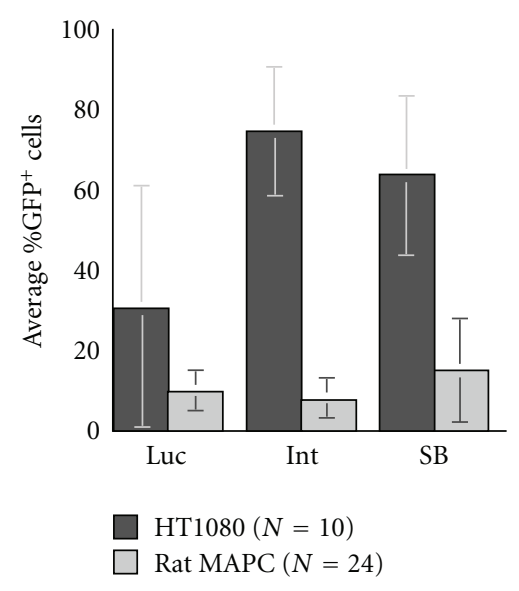

(d)

FIgUre 5: Stability of gene expression in MAPC. (a) Percentage GFP positive cells determined by flow cytometric analysis of 24 independent G418-resistant clones expanded from MAPC cotransfected with pKT2/NAG and Luc, SB, or Int expression vectors. Mean percentages of GFP+ cells for each condition are indicated by black bars. (b) Southern hybridization analysis of SB- and $\phi$ C31-mediated integration events. Top shows a schematic representation of the 6709 bp circular plasmid nucleofected into rat MAPC and the location of the GFP probe. See legend of Figure 1 for explanation of sequence elements contained in the vector. SpeI and BamHI restriction sites were used for digestion of high molecular weight genomic DNA isolated from each G418-resistant clone. The SpeI site is located $2.4 \mathrm{~kb}$ from the breakpoint in the attB site. The BamHI site is located $3.5 \mathrm{~kb}$ from the right IR/DR. The bottom figure shows the hybridization image of genomic DNA digested with SpeI $(\phi \mathrm{C} 31)$ and BamHI (SB) hybridized with the GFP probe. Clone number is indicated across the top, and marker positions are indicated along the sides. (c) Flow cytometry of representative stable G418-resistant clones exhibiting GFP expression in HT1080 human fibroblasts and rat multipotent adult progenitor cells (rMAPCs) with integrating vector alone (left panel), integrating vector plus $\phi$ C31 integrase (middle panel) and integrating vector plus SB transposase (right panel) compared to mock transfected cells of each type (black). (d) FACS analysis of individual clones was also measured and the average \%GFP+ cells determined. Bar graph showing the average GFP\% expression in HT12080 (dark bars) and rMAPC (light bars). Error bars represent standard deviation.

(Figure 4(b)). To further quantify and compare the differentiation levels between the different methods, both end point RT-PCR and qRT-PCR analyses of RNA isolated from these cells were positive for expression of endothelium (Flk-1, Flt1, and Eg1) or hepatocyte (HNF3b, AFP, and TTR) specific markers (Figure 4(c) and Table 1). These results demonstrate that MAPC genetically engineered using SB or $\phi \mathrm{C} 31$ maintain their stem-cell character and their ability to differentiate into multiple cellular lineages upon induction.
3.4. Strength of Gene Expression in MAPC. The strength of gene expression was determined for the GFP reporter. Twenty-four drug-resistant clones were randomly isolated for both SB and $\phi \mathrm{C} 31$ that had been expanded in G418containing medium for an additional 3-4 weeks. The levels of GFP expression were determined for each independent clone by flow cytometry (Figure 5(a)). Although all of the clones were G418 resistant, GFP intensity of most clones was low with only a few percentage of the cells exhibiting 
TABLE 1: qRTPCR analysis of differentiated rMAPC. Endothelium markers Flk1, Flt1, and Eg1 and liver markers HNF3b, AFP, and TTR were measured and $\mathrm{Ct}$ values normalized to GAPDH levels to determine $\Delta \mathrm{Ct}$. Adult rat liver was used as the positive control and corresponding undifferentiated cells as negative control. Relative expression was carried out by determining $\Delta \mathrm{Ct}$ values and comparing expression levels to the positive control sample.

\begin{tabular}{|c|c|c|c|c|c|c|c|c|c|}
\hline & \multicolumn{3}{|c|}{ FIk1 } & \multicolumn{3}{|c|}{ FIt1 } & \multicolumn{3}{|c|}{ Eg1 } \\
\hline & $\Delta \mathrm{Ct}$ & $\mathrm{SD}$ & Rel Exp & $\Delta \mathrm{Ct}$ & SD & Rel Exp & $\Delta \mathrm{Ct}$ & $\mathrm{SD}$ & Rel Exp \\
\hline MAPC & 20.13 & 4.95 & 0.00006 & 15.23 & 11.81 & 0.00071 & 4.46 & 0.7 & 0.23982 \\
\hline Luc & 8.34 & 0.35 & 0.22298 & 2.42 & 0.69 & 5.09824 & 1.79 & 0.69 & 1.52626 \\
\hline Int & 10.13 & 0.15 & 0.0647 & 2.61 & 0.34 & 4.46915 & 2.28 & 0.33 & 1.08673 \\
\hline SB & 8.84 & 0.63 & 0.15822 & 2.46 & 0.06 & 4.95883 & 1.8 & 0.13 & 1.51572 \\
\hline \multirow[t]{3}{*}{ Adult rLiver } & 6.18 & 1.23 & 1 & 4.77 & 0.45 & 1 & 2.4 & 0.1 & 1 \\
\hline & \multicolumn{3}{|c|}{ HNF3b } & \multicolumn{3}{|c|}{ AFP } & \multicolumn{3}{|c|}{ TTR } \\
\hline & $\Delta \mathrm{Ct}$ & SD & Rel Exp & $\Delta \mathrm{Ct}$ & SD & Rel Exp & $\Delta \mathrm{Ct}$ & $\mathrm{SD}$ & Rel Exp \\
\hline MAPC & 3.27 & 0.21 & 1.38992 & 22.03 & 0.5 & 0 & 13.34 & 0.57 & 0 \\
\hline Luc & 2.6 & 0.16 & 2.21914 & 16.42 & 0.32 & 0.0002 & 13.22 & 0.25 & 0 \\
\hline Int & 2.51 & 0.14 & 2.35381 & 10.99 & 6.1 & 0.00867 & 3.95 & 1.96 & 0.0003 \\
\hline SB & 1.78 & 0.35 & 3.90413 & 6.43 & 0.26 & 0.20448 & 1.95 & 0.2 & 0.0012 \\
\hline Adult rLiver & 3.75 & 0.22 & 1 & 4.14 & 0.15 & 1 & neg7.76 & 0.09 & 1 \\
\hline
\end{tabular}

HNF3b: hepatocyte nuclear factor-3-beta; AFP: alpha-fetoprotein; TTR: transthyretin for liver differentiation, and Flk1: vascular endothelial growth factor receptor-2; Flt1: vascular endothelial growth factor receptor-1; Eg1: endothelial-derived gene-1 for differentiation into endothelium. Total RNA isolated from adult rat liver tissue (rLiver) was used as a positive control for liver and endothelial markers and undifferentiated MAPC (MAPC) used as the negative control.

expression above background. The clones were grouped into three categories based on percentage (\%) of cells with GFP expression above background: low $\leq 5 \% \mathrm{GFP}^{+}$; intermediate: $10-20 \% \mathrm{GFP}^{+}$; and high $\geq 20 \% \mathrm{GFP}^{+}$. Using these criteria, we found that the majority of the G418resistant clones contained a low or intermediate percentage of GFP-expressing cells, including 23/24 clones generated by random integration, 23/24 by PhiC31 integrase, and 18/24 by SB transposase, with only 1 of the SB-mediated clones exhibiting significantly higher levels of GFP expression.

To determine the effect of each recombinase on integrant copy number, we studied the average number of integrants per MAPC clone by Southern blot analysis. Genomic DNA isolated from 10 out of 24 randomly selected G418-resistant MAPC clones was digested with enzymes that cut once within the integrating vector sequence, generating GFPhybridizing fragments of varying size for each integrant and providing an assessment of the number of stable insertions mediated by SB transposase or $\phi \mathrm{C} 31$ integrase (Figure 5(b)). The number of integrants among the SB-mediated stable clones was $6 \pm 3$, with one G418-resistant clone (number 7) showing at least 12 independent integrants. This value was 3 -fold higher than previously described for SB10-mediated insertions in cultured human fibroblasts (1-2 transposon integrants per clone) $[50,56,57]$. Interestingly, human fibroblasts with 1-2 genomic integrants per clone exhibited stable gene expression, while MAPC with an increased number of integrants showed weak transgene expression. There were fewer integrants per clone in the case of $\phi \mathrm{C} 31$ integrase-mediated gene transfer $(3 \pm 1)$, likely resulting from the site-preferred character of this vector system.

Interestingly, transgene expression in the MAPC clones was significantly lower compared to clones obtained with

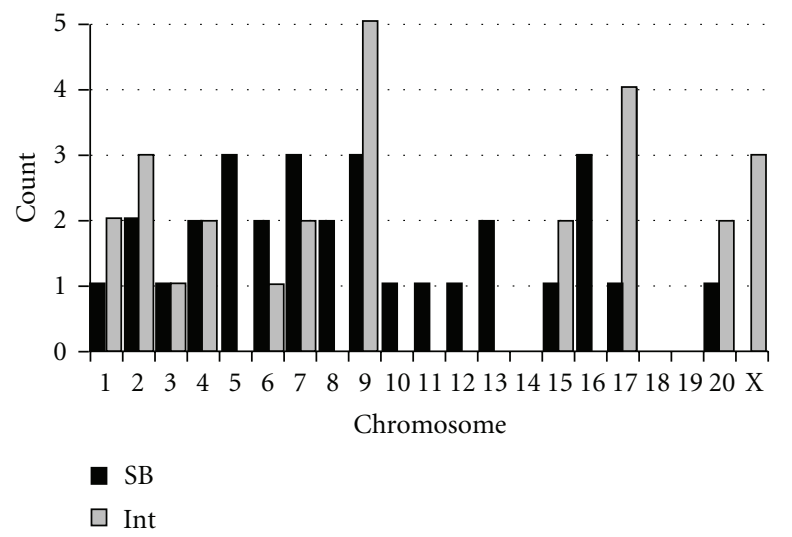

Figure 6: Chromosomal distribution of SB and $\phi \mathrm{C} 31$ integrants. Integrants with flanking sequence were recovered from the genome of MAPC by either linker-mediated PCR (SB; grey bars) or plasmid rescue ( $\phi$ C31; black bars); the frequency and distribution of independent events is displayed.

the same construct in HT1080 (Figure 5(c)). Analysis of average GFP+ cells in individual clones obtained in HT1080 and rMAPC further confirm this observation (Figure 5(d)). These results suggest either low copy number integration, epigenetic suppression of the promoter-transgene elements [58], or integration at a genomic site that does not support active transcription.

3.5. Molecular Analysis of Integration Sites in Isolated MAPC Clones. Several integrants were further characterized at the sequence level using either linker-mediated PCR (SB) or plasmid rescue ( $\phi$ C31) techniques (see Section 2.7). For SB, 
TABLE 2: $\phi \mathrm{C} 31$ and SB chromosome junction sequences recovered from rat MAPC. Around 10 each of drug-resistant clones obtained with PhiC31 integrase and SB transposase were chosen at random to determine the site of genomic integration. Most clones showed more than one integration event, consistent with southern blot results. Exact genomic locations were determined by comparison of the chromosomal junction sequence with that of the rat genome.

(a)

\begin{tabular}{|c|c|c|}
\hline \multicolumn{3}{|c|}{$\phi$ C31 Integrase } \\
\hline Clone & Chromosome band & Location \\
\hline \multirow[t]{2}{*}{1} & $4 q 42$ & 158791838 \\
\hline & $9 q 22$ & 51217205 \\
\hline \multirow[t]{4}{*}{2} & $2 q 44$ & 236122145 \\
\hline & $9 q 22$ & 51217122 \\
\hline & $15 q 11$ & 58645720 \\
\hline & $17 q 12.1$ & 57593447 \\
\hline \multirow[t]{5}{*}{3} & $2 q 26$ & 141365031 \\
\hline & $3 \mathrm{q} 21$ & 51055488 \\
\hline & $7 q 13$ & 32562140 \\
\hline & $15 q 12$ & 66145915 \\
\hline & $20 \mathrm{q} 12$ & 4538590 \\
\hline \multirow[t]{4}{*}{4} & $2 q 34 s$ & 199022700 \\
\hline & $7 q 13$ & 32562264 \\
\hline & $9 q 22$ & 51217198 \\
\hline & $20 \mathrm{q} 12$ & 5244926 \\
\hline \multirow[t]{4}{*}{5} & $4 \mathrm{q} 41$ & 139277121 \\
\hline & $6 q 12$ & 11098254 \\
\hline & $9 q 22$ & 51217202 \\
\hline & $\mathrm{Xq} 12$ & 18543448 \\
\hline \multirow[t]{2}{*}{6} & $17 q 12.1$ & 57594096 \\
\hline & $\mathrm{Xq} 35$ & 134407720 \\
\hline \multirow[t]{3}{*}{7} & $1 \mathrm{q} 41$ & 193493175 \\
\hline & $17 q 12.1$ & 57593343 \\
\hline & $\mathrm{Xq} 35$ & 134407720 \\
\hline \multirow[t]{2}{*}{8} & $1 \mathrm{q} 41$ & 193493175 \\
\hline & $9 q 22$ & 51217207 \\
\hline 9 & $17 \mathrm{q} 12.1$ & 57593353 \\
\hline
\end{tabular}

(b)

\begin{tabular}{lcc}
\hline Clone & $\begin{array}{c}\text { SB Transposase } \\
\text { Chromosome band }\end{array}$ & Location \\
\hline 1 & $2 \mathrm{q} 33$ & 171779390 \\
& $13 \mathrm{q} 11$ & 32001139 \\
$13 \mathrm{q} 11$ & 39927168 \\
& $20 \mathrm{q} 12$ & 44445336 \\
\hline 2 & $16 \mathrm{p} 14$ & 13906741 \\
\hline 3 & $1 \mathrm{p} 11$ & 34991484 \\
& $7 \mathrm{q} 32$ & 94455924 \\
& $9 \mathrm{q} 36$ & 97344920 \\
\hline 4 & $6 \mathrm{q} 32$ & 128228570 \\
& $8 \mathrm{q} 24$ & 59559434 \\
& $15 \mathrm{q} 24$ & 104110283 \\
& $16 \mathrm{q} 12.1$ & 57613884 \\
\hline 5 & $5 \mathrm{q} 35$ & 128927150 \\
& $11 \mathrm{q} 23$ & 77290939 \\
\hline
\end{tabular}

(b) Continued.

\begin{tabular}{lcc}
\hline Clone & $\begin{array}{c}\text { SB Transposase } \\
\text { Chromosome band }\end{array}$ & Location \\
\hline 6 & $3 \mathrm{q} 35$ & 102093005 \\
& $4 \mathrm{q} 22$ & 59940513 \\
& $4 \mathrm{q} 23$ & 71432455 \\
& $5 \mathrm{q} 35$ & 134761715 \\
& $16 \mathrm{q} 12.2$ & 60379119 \\
\hline 7 & $6 \mathrm{q} 13$ & 23449543 \\
& $17 \mathrm{q} 11$ & 49437069 \\
\hline 8 & $7 \mathrm{q} 12$ & 16815756 \\
& $8 \mathrm{q} 24$ & 77171774 \\
& $9 \mathrm{q} 11$ & 7186249 \\
\hline 9 & $9 \mathrm{q} 36$ & 90439317 \\
& $12 \mathrm{p} 12$ & 2500679 \\
\hline 10 & $2 \mathrm{q} 11$ & 6206693 \\
& $5 \mathrm{q} 21$ & 48519577 \\
& $7 \mathrm{q} 13$ & 28888887 \\
& $10 \mathrm{q} 26$ & 75143457 \\
\hline
\end{tabular}

TABle 3: Correlation of GFP expression and integration site for $\phi$ C31 Integrase. Three clones were selected based on the expression level of GFP (high, medium, or low). Plasmid rescue was carried out to determine if the expression level correlated with integrant number or genomic location.

\begin{tabular}{lccc}
\hline Clone & \%GFP & Chromosome band & Position \\
\hline \multirow{2}{*}{ Lo } & $<5 \%$ & $5 \mathrm{q} 12$ & 18035560 \\
& $<5 \%$ & $17 \mathrm{q} 12.1$ & 57593963 \\
& $<5 \%$ & $\mathrm{Xq} 35$ & 134407720 \\
\hline \multirow{2}{*}{ Med } & $10-20 \%$ & $1 \mathrm{q} 41$ & 193493175 \\
& $10-20 \%$ & $17 \mathrm{q} 12.1$ & 57594096 \\
\hline \multirow{4}{*}{ Hi } & $>20 \%$ & $8 \mathrm{q} 31$ & 93775192 \\
& $>20 \%$ & $10 \mathrm{q} 31$ & 87259340 \\
& $>20 \%$ & $17 \mathrm{q} 12.1$ & 57594096 \\
& $>20 \%$ & $\mathrm{Xq} 35$ & 134407720 \\
\hline
\end{tabular}

we recovered 30 unique transposon: chromosome junction sequences that mapped to positions on 17 independent chromosomes (Figure 6 and Table 2). We also obtained 27 distinct $\phi \mathrm{C} 31$ integrants that were distributed over 11 chromosomes (Figure 6 and Table 3). MAPC clones generated using $\mathrm{SB}$ exhibited a relatively random distribution of integration, while $\phi \mathrm{C} 31$ treated MAPC revealed an enrichment for specific sequences on chromosomes X, 9, and 17 (Tables 2 and 4). As these sites were represented in multiple independent clones, we decided to test three clones demonstrating high, medium, or low GFP expression with respect to integrant number and genomic location (Table 3). This analysis revealed that neither the number of integrants per clone nor the genomic location of the integrant was associated with GFP expression level. The clone exhibiting a higher percentage of $\mathrm{GFP}^{+}$cells had 4 integrants, while clones characterized as having medium or low levels of expression had 2 and 3 integrants each, respectively. Furthermore, the clone demonstrating increased expression of GFP (Hi) contained insertions on chromosomes X and 17 similar to the clone demonstrating reduced GFP expression 
TABLE 4: Hotspots for $\phi \mathrm{C} 31$-mediated integration in the genome of rat MAPC. Nine drug-resistant clones and an additional three clones picked on the basis of GFP expression were analyzed for integrant number and genomic location. Of all the integration sites identified, the location on chromosome 17 (17q12.1) was found to be targeted with highest frequency ( 7 out of 12 clones) followed by chromosome locations 9q22 (5 out of 12 clones) and Xq35 (4 out of 12 clones). Exact genomic location of the integrant and the nearest gene to the site of integration is listed for each chromosome hotspot.

\begin{tabular}{|c|c|c|c|c|}
\hline Chrom. & Clone & $\begin{array}{c}\text { Chromosome } \\
\text { band }\end{array}$ & Position & $\begin{array}{l}\text { Nearest } \\
\text { gene }\end{array}$ \\
\hline \multirow[t]{7}{*}{17} & 2 & 17q12.1 & 57593447 & \\
\hline & 6 & & 57594096 & \\
\hline & 7 & & 57593343 & \\
\hline & 9 & & 57593353 & $\begin{array}{c}\text { ATI4B } \\
59334046-59457079\end{array}$ \\
\hline & Lo & & 57593962 & \\
\hline & Med & & 57594096 & \\
\hline & $\mathrm{Hi}$ & & 57594096 & \\
\hline \multirow[t]{5}{*}{9} & 1 & $9 q 22$ & 51217205 & \\
\hline & 2 & & 51217122 & \\
\hline & 4 & & 51217198 & $\begin{array}{c}\text { SDPR } \\
47373044-47385061\end{array}$ \\
\hline & 5 & & 51217202 & \\
\hline & 8 & & 51217207 & \\
\hline \multirow[t]{4}{*}{$\mathrm{X}$} & 6 & Xq35 & 134407720 & \\
\hline & 7 & & 134407720 & $\begin{array}{c}\text { Xpnpep2 } \\
134474700- \\
134501921\end{array}$ \\
\hline & Lo & & 134407720 & \\
\hline & $\mathrm{Hi}$ & & 134407720 & \\
\hline
\end{tabular}

(Lo), while integration on chromosome 9 was not detected. Similarly, additionally analyzed clones with over 5 integrants per cell did not exhibit high levels of GFP expression. These data suggest that the number of integrants or the genomic location of integrants alone may not dictate persistence in expression of the transgene but a combination of these along with other epigenetic factors could play a key determining role.

\section{Discussion}

In this study, we used an internally controlled bifunctional plasmid to deliver expression cassettes encoding GFP or neomycin phosphotransferase along with both components of the $\phi \mathrm{C} 31$ and $\mathrm{SB}$ integrating systems into cultured human fibroblasts and rat multipotent adult progenitor cells (rMAPC). Both systems effectively mediated stable gene transfer resulting through recombinase-mediated integration of exogenous sequences. Genetically modified rMAPC maintained their stem cell features, demonstrated by the ability to differentiate into endothelium and liver tissues in the presence of specific cytokines. Silencing of GFP was observed for each system when G418-resistant rMAPC were expanded in culture. Southern blot analysis demonstrated that the number of integrants among the SB-transposed stable clones was $6 \pm 3$ while fewer independent integrants were detected for $\phi \mathrm{C} 31$ integrase engineered cell lines $(3 \pm$ $1)$.

Non-viral, DNA-mediated gene transfer has been explored as a means of potential gene therapy targeting a variety of different cell types in vitro and in vivo. One longrange goal is to test non-viral integrating vector systems for the capacity to mediate stable, DNA-mediated gene transfer in hematopoietic stem cells (HSC). Genetic engineering of HSC with the capacity to complete long-term repopulation of the hematopoietic system has previously been accomplished with the use of integrating viral vectors and has been reported using the SB transposon system [36, 37]. Unlike HSC, MAPC are capable of long-term self-renewal in culture and can be induced to differentiate with specific cytokines to form multiple cell types. These characteristics provide a unique resource for testing: (i) non-viral gene transfer in primitive stem cells, (ii) the effect of genetic engineering on maintenance of the stem cell character, (iii) stability of transgene expression following differentiation, and (iv) insertion site profiles on a genome wide scale, with the potential for functional screening in a primitive and differentiating cell system.

Therapeutic application of stem cells for the correction of genetic disorders will likely require long-term expression of newly introduced therapeutic genes, most effectively accomplished by integration of the transgene. However, along with the incorporation of exogenous elements into chromosomal DNA comes the potential for adverse effects resulting from insertional mutagenesis. Integration could lead to deregulated expression of tumor suppressor genes, oncogenes, or cell-cycle regulatory genes resulting in cancer [59-63]. As a result, genome-wide analyses of the insertionsite preferences for integrating vectors are being explored in a variety of target cells and tissues $[60,61,64,65]$.

SB transposons exhibit a relatively random integration pattern in mammalian genomes [66-68] and may be less likely to integrate into transcribed genes or transcriptional regulatory regions than other integrating vectors such as retroviruses and lentiviruses [66, 67, 69]. Having a comparable gene transfer efficiency, $\phi \mathrm{C} 31$ integrase displays preference for a seemingly limited number of insertion target sites in mammalian genomes, benefiting from sequence requirements of "pseudo attP" sites. In fact, analysis of several $\phi \mathrm{C} 31$-mediated integration events suggests that preferential sites for integration exist in both the mouse and human genomes consistent with at most $30-40 \%$ partial sequence homology to the wild-type phage attP target [20, $40,42]$. These data suggest that $\phi \mathrm{C} 31$ integrase-mediated DNA insertion is a relatively site-preferred approach for achieving persistent gene expression through integration.

A common limitation of viral or plasmid-based integration in undifferentiated cells is gene silencing that occurs during expansion or differentiation of the target population. This quenching of expression is likely caused by epigenetic effects such as methylation of transcriptional regulatory sequences or inhibition of transcription factor binding through chromatin condensation and genome remodeling. 
Our results indicate that while SB transposase achieves multiple integrations per clone, $\phi \mathrm{C} 31$ integrase mediates an average of 2-4 integrations per clone. This is more than what has been reported for mouse and human cells (an average of 1 integration site per clone $[42,43]$ ) and could either be due to the concentration of integrating plasmid used or the ratio of integrating plasmid to $\phi \mathrm{C} 31$ integrase. Alternately, rat cells in general or stem cells such as MAPC in particular might have a more open chromatin structure, thus exposing more "pseudo attP" sites for targeting by the PhiC31 integrase.

The only other study reporting successful use of PhiC31 integrase in rat cells was performed using the rat embryonic fibroblast cell line (Rat2) to first identify preferential sites of genomic integration. Based on these preferential sites, a PCRbased method was developed to characterize $\phi \mathrm{C} 31$-mediated integration events in retinal pigment epithelial cells following direct injection and subsequent in vivo electroporation [70]. From this methodology, three sites on chromosomes 12q16, $1 \mathrm{q} 41$, and $2 \mathrm{q} 26$ were determined to be preferential targets with each displaying a limited level of sequence homology to each other and with the $\phi \mathrm{C} 31$ attP site. Our results confirm the finding that preferential $\phi \mathrm{C} 31$ targets exist on 1q41 and 2 q26 and extend this observation to identify three new targets which represented a higher frequency of integration events on chromosomes 17q12.1, 9q22, and Xq35. It is possible that these genomic hotspots for PhiC31 integration identified in rat MAPC are unique due to the nature of the chromatin in these undifferentiated cells.

\section{Conclusions}

We report here a relatively high efficiency of non-viral modification of MAPC using the SB transposon and the PhiC31 phage integrase, where SB can be used to achieve higher gene expression and PhiC31 for fewer integration sites but reduced expression levels. While both systems offer an alternative to viral methods of gene transfer into multipotent adult progenitor cells as well as other types of stem cells, still needed are comparative studies designed to characterize maintenance of gene expression after differentiation.

\section{Acknowledgments}

The authors thank the Masonic Cancer Center Cytogenetics Core facility at the University of Minnesota for performing cytogenetic analysis. This work was supported by grants from the Fanconi Anemia Research Foundation Grant (U. Lakshmipathy), Lymphoma and Leukemia society Translation Grant (U. Lakshmipathy), Arnold and Mabel Beckman Foundation (R. S. McIvor), NIGMS training Grant no. T32 GM08347, and University of Minnesota Doctoral Dissertation Fellowship (A. Wilber). A. Wilber and F. U. Montoya contributed equally to this work.

\section{References}

[1] Y. Jiang, B. N. Jahagirdar, R. L. Reinhardt et al., "Pluripotency of mesenchymal stem cells derived from adult marrow," Nature, vol. 418, no. 6893, pp. 41-49, 2002.
[2] M. Reyes and C. M. Verfaillie, "Characterization of multipotent adult progenitor cells, a subpopulation of mesenchymal stem cells," Annals of the New York Academy of Sciences, vol. 938, pp. 231-235, 2001.

[3] L. R. Zhao, W. M. Duan, M. Reyes, C. M. Verfaillie, and W. C. Low, "Immunohistochemical identification of multipotent adult progenitor cells from human bone marrow after transplantation into the rat brain," Brain Research Protocols, vol. 11, no. 1, pp. 38-45, 2003.

[4] Y. Jiang, D. Henderson, M. Blackstad, A. Chen, R. F. Miller, and C. M. Verfaillie, "Neuroectodermal differentiation from mouse multipotent adult progenitor cells," Proceedings of the National Academy of Sciences of the United States of America, vol. 100, no. 1, pp. 11854-11860, 2003.

[5] C. D. Keene, X. R. Ortiz-Gonzalez, Y. Jiang, D. A. Largaespada, C. M. Verfaillie, and W. C. Low, "Neural differentiation and incorporation of bone marrow-derived multipotent adult progenitor cells after single cell transplantation into blastocyst stage mouse embryos," Cell Transplantation, vol. 12, no. 3, pp. 201-213, 2003.

[6] M. Reyes, A. Dudek, B. Jahagirdar, L. Koodie, P. H. Marker, and C. M. Verfaillie, "Origin of endothelial progenitors in human postnatal bone marrow," The Journal of Clinical Investigation, vol. 109, no. 3, pp. 337-346, 2002.

[7] R. E. Schwartz, M. Reyes, L. Koodie et al., "Multipotent adult progenitor cells from bone marrow differentiate into functional hepatocyte-like cells," The Journal of Clinical Investigation, vol. 109, no. 10, pp. 1291-1302, 2002.

[8] M. Serafini, S. J. Dylla, M. Oki et al., "Hematopoietic reconstitution by multipotent adult progenitor cells: precursors to long-term hematopoietic stem cells," Journal of Experimental Medicine, vol. 204, no. 1, pp. 129-139, 2007.

[9] X. L. Aranguren, J. D. McCue, B. Hendrickx et al., "Multipotent adult progenitor cells sustain function of ischemic limbs in mice," The Journal of Clinical Investigation, vol. 118, no. 2, pp. 505-514, 2008.

[10] B. Pelacho, Y. Nakamura, J. Zhang et al., "Multipotent adult progenitor cell transplantation increases vascularity and improves left ventricular function after myocardial infarction," Journal of Tissue Engineering and Regenerative Medicine, vol. 1, no. 1, pp. 51-59, 2007.

[11] J. Tolar, X. Wang, E. Braunlin et al., "The host immune response is essential for the beneficial effect of adult stem cells after myocardial ischemia," Experimental Hematology, vol. 35, no. 4, pp. 682-690, 2007.

[12] I. Dimomeletis, E. Deindl, M. Zaruba et al., "Assessment of human MAPCs for stem cell transplantation and cardiac regeneration after myocardial infarction in SCID mice," Experimental Hematology, vol. 38, no. 11, pp. 1105-1114, 2010.

[13] M. Kovacsovics-Bankowski, P. R. Streeter, K. A. Mauch et al., "Clinical scale expanded adult pluripotent stem cells prevent graft-versus-host disease," Cellular Immunology, vol. 255, no. 1-2, pp. 55-60, 2009.

[14] S. L. Highfill, R. M. Kelly, M. J. O’Shaughnessy et al., "Multipotent adult progenitor cells can suppress graft-versus-host disease via prostaglandin E2 synthesis and only if localized to sites of allopriming," Blood, vol. 114, no. 3, pp. 693-701, 2009.

[15] R. H. A. Plasterk, Z. Izsvák, and Z. Ivics, "Resident aliens the Tc1/mariner superfamily of transposable elements," Trends in Genetics, vol. 15, no. 8, pp. 326-332, 1999.

[16] Z. Ivics, P. B. Hackett, R. H. Plasterk, and Z. Izsvák, "Molecular reconstruction of sleeping beauty, a Tc1-like transposon from 
fish, and its transposition in human cells," Cell, vol. 91, no. 4, pp. 501-510, 1997.

[17] Z. Izsvák, Z. Ivics, and R. H. Plasterk, "Sleeping beauty, a wide host-range transposon vector for genetic trensformation in vertebrates," Journal of Molecular Biology, vol. 302, no. 1, pp. 93-102, 2000.

[18] A. Wilber, J. L. Frandsen, J. L. Geurts, D. A. Largaespada, P. B. Hackett, and R. S. McIvor, "RNA as a source of transposase for Sleeping Beauty-mediated gene insertion and expression in somatic cells and tissues," Molecular Therapy, vol. 13, no. 3, pp. 625-630, 2006.

[19] A. D. Converse, L. R. Belur, J. L. Gori et al., "Counterselection and co-delivery of transposon and transposase functions for Sleeping Beauty-mediated transposition in cultured mammalian cells," Bioscience Reports, vol. 24, no. 6, pp. 577-594, 2004.

[20] A. Ehrhardt, H. Xu, Z. Huang, J. A. Engler, and M. A. Kay, "A direct comparison of two nonviral gene therapy vectors for somatic integration: in vivo evaluation of the bacteriophage integrase $\varphi \mathrm{C} 31$ and the Sleeping Beauty transposase," Molecular Therapy, vol. 11, no. 5, pp. 695-706, 2005.

[21] J. G. Mikkelsen, S. R. Yant, L. Meuse, Z. Huang, H. Xu, and M. A. Kay, "Helper-independent Sleeping Beauty transposontransposase vectors for efficient nonviral gene delivery and persistent gene expression in vivo," Molecular Therapy, vol. 8, no. 4, pp. 654-665, 2003.

[22] E. Montini, P. K. Held, M. Noll et al., "In vivo correction of murine tyrosinemia type I by DNA-mediated transposition," Molecular Therapy, vol. 6, no. 6, pp. 759-769, 2002.

[23] J. R. Ohlfest, J. L. Frandsen, S. Fritz et al., "Phenotypic correction and long-term expression of factor VIII in hemophilic mice by immunotolerization and nonviral gene transfer using the Sleeping Beauty transposon system," Blood, vol. 105, no. 7, pp. 2691-2698, 2005.

[24] P. R. Score, L. R. Belur, J. L. Frandsen et al., "Sleeping beauty-mediated transposition and long-term expression in vivo: use of the LoxP/Cre recombinase system to distinguish transposition-specific expression," Molecular Therapy, vol. 13, no. 3, pp. 617-624, 2006.

[25] S. R. Yant, L. Meuse, W. Chiu, Z. Ivics, Z. Izsvak, and M. A. Kay, "Somatic integration and long-term transgene expression in normal and haemophilic mice using a DNA transposon system," Nature Genetics, vol. 25, no. 1, pp. 35-41, 2000.

[26] S. Ortiz-Urda, Q. Lin, S. R. Yant, D. Keene, M. A. Kay, and P. A. Khavari, "Sustainable correction of junctional epidermolysis bullosa via transposon-mediated nonviral gene transfer," Gene Therapy, vol. 10, no. 13, pp. 1099-1104, 2003.

[27] L. R. Belur, J. L. Frandsen, A. J. Dupuy et al., "Gene insertion and long-term expression in lung mediated by the Sleeping Beauty transposon system," Molecular Therapy, vol. 8, no. 3, pp. 501-507, 2003.

[28] L. Liu, C. Mah, and B. S. Fletcher, "Sustained FVIII expression and phenotypic correction of hemophilia A in neonatal mice using an endothelial-targeted sleeping beauty transposon," Molecular Therapy, vol. 13, no. 5, pp. 1006-1015, 2006.

[29] L. Liu, S. Sanz, A. D. Heggestad, V. Antharam, L. Notterpek, and B. S. Fletcher, "Endothelial targeting of the Sleeping Beauty transposon within lung," Molecular Therapy, vol. 10, no. 1, pp. 97-105, 2004.

[30] X. Huang, A. C. Wilber, L. Bao et al., "Stable gene transfer and expression in human primary $\mathrm{T}$ cells by the Sleeping Beauty transposon system," Blood, vol. 107, no. 2, pp. 483-491, 2006.

[31] G. Luo, Z. Ivics, Z. Izsvák, and A. Bradley, "Chromosomal transposition of a Tc1/mariner-like element in mouse embryonic stem cells," Proceedings of the National Academy of Sciences of the United States of America, vol. 95, no. 18, pp. 10769-10773, 1998.

[32] K. Yusa, J. Takeda, and K. Horie, "Enhancement of Sleeping Beauty transposition by $\mathrm{CpG}$ methylation: possible role of heterochromatin formation," Molecular and Cellular Biology, vol. 24, no. 9, pp. 4004-4018, 2004.

[33] A. Wilber, J. L. Linehan, X. Tian et al., "Efficient and stable transgene expression in human embryonic stem cells using transposon-mediated gene transfer," Stem Cells, vol. 25, no. 11, pp. 2919-2927, 2007.

[34] T. I. Orbán, A. Apáti, A. Németh et al., "Applying a "doublefeature" promoter to identify cardiomyocytes differentiated from human embryonic stem cells following transposonbased gene delivery," Stem Cells, vol. 27, no. 5, pp. 1077-1087, 2009.

[35] J. Tolar, M. Osborn, S. Bell et al., "Real-time in vivo imaging of stem cells following transgenesis by transposition," Molecular Therapy, vol. 12, no. 1, pp. 42-48, 2005.

[36] X. Xue, X. Huang, S. E. Nodland et al., "Stable gene transfer and expression in cord blood-derived CD34+ hematopoietic stem and progenitor cells by a hyperactive Sleeping Beauty transposon system," Blood, vol. 114, no. 7, pp. 1319-1330, 2009.

[37] L. Mátés, M. K. L. Chuah, E. Belay et al., "Molecular evolution of a novel hyperactive Sleeping Beauty transposase enables robust stable gene transfer in vertebrates," Nature Genetics, vol. 41, no. 6, pp. 753-761, 2009.

[38] H. M. Thorpe and M. C. M. Smith, "In vitro site-specific integration of bacteriophage DNA catalyzed by a recombinase of the-resolvase/invertase family," Proceedings of the National Academy of Sciences of the United States of America, vol. 95, no. 10, pp. 5505-5510, 1998.

[39] A. C. Groth, E. C. Olivares, B. Thyagarajan, and M. P. Calos, "A phage integrase directs efficient site-specific integration in human cells," Proceedings of the National Academy of Sciences of the United States of America, vol. 97, no. 11, pp. 5995-6000, 2000.

[40] B. Thyagarajan, E. C. Olivares, R. P. Hollis, D. S. Ginsburg, and M. P. Calos, "Site-specific genomic integration in mammalian cells mediated by phage $\varphi \mathrm{C} 31$ integrase," Molecular and Cellular Biology, vol. 21, no. 12, pp. 3926-3934, 2001.

[41] A. C. Groth and M. P. Calos, "Phage integrases: biology and applications," Journal of Molecular Biology, vol. 335, no. 3, pp. 667-678, 2004.

[42] T. W. Chalberg, J. L. Portlock, E. C. Olivares et al., "Integration specificity of phage $\varphi \mathrm{C} 31$ integrase in the human genome," Journal of Molecular Biology, vol. 357, no. 1, pp. 28-48, 2006.

[43] P. K. Held, E. C. Olivares, C. P. Aguilar, M. Finegold, M. P. Calos, and M. Grompe, "In vivo correction of murine hereditary tyrosinemia type I by $\varphi \mathrm{C} 31$ integrase-mediated gene delivery," Molecular Therapy, vol. 11, no. 3, pp. 399-408, 2005.

[44] E. C. Olivares, R. P. Hollis, T. W. Chalberg, L. Meuse, M. A. Kay, and M. P. Calos, "Site-specific genomic integration produces therapeutic factor IX levels in mice," Nature Biotechnology, vol. 20, no. 11, pp. 1124-1128, 2002.

[45] S. Ortiz-Urda, B. Thyagarajan, D. R. Keene, Q. Lin, M. P. Calos, and P. A. Khavari, " $\varphi$ C31 integrase-mediated nonviral genetic correction of junctional epidermolysis bullosa," Human Gene Therapy, vol. 14, no. 9, pp. 923-928, 2003.

[46] S. P. Quenneville, P. Chapdelaine, J. Rousseau et al., "Nucleofection of muscle-derived stem cells and myoblasts with $\varphi \mathrm{C} 31$ integrase: stable expression of a full-length-dystrophin fusion 
gene by human myoblasts," Molecular Therapy, vol. 10, no. 4, pp. 679-687, 2004.

[47] G. Belteki, M. Gertsenstein, D. W. Ow, and A. Nagy, "Sitespecific cassette exchange and germline transmission with mouse ES cells expressing $\varphi$ C31 integrase," Nature Biotechnology, vol. 21, no. 3, pp. 321-324, 2003.

[48] Y. Liu, B. Thyagarajan, U. Lakshmipathy et al., "Generation of platform human embryonic stem cell lines that allow efficient targeting at a predetermined genomic location," Stem Cells and Development, vol. 18, no. 10, pp. 1459-1471, 2009.

[49] Z. Cui, A. M. Geurts, G. Liu, C. D. Kaufman, and P. B. Hackett, "Structure-function analysis of the inverted terminal repeats of the Sleeping Beauty transposon," Journal of Molecular Biology, vol. 318, no. 5, pp. 1221-1235, 2002.

[50] A. M. Geurts, Y. Yang, K. J. Clark et al., "Gene transfer into genomes of human cells by the Sleeping Beauty transposon system," Molecular Therapy, vol. 8, no. 1, pp. 108-117, 2003.

[51] A. Wilber, J. L. Frandsen, K. J. Wangensteen, S. C. Ekker, X. Wang, and R. S. McIvor, "Dynamic gene expression after systemic delivery of plasmid DNA as determined by in vivo bioluminescence imaging," Human Gene Therapy, vol. 16, no. 11, pp. 1325-1332, 2005.

[52] U. Lakshmipathy, B. Pelacho, K. Sudo et al., "Efficient transfection of embryonic and adult stem cells," Stem Cells, vol. 22, no. 4, pp. 531-543, 2004.

[53] U. Lakshmipathy, L. Hammer, and C. Verfaillie, "METHODa nonviral gene transfer method for transfecting multipotent adult progenitor cells (MAPC)," Gene Therapy and Regulation, vol. 2, no. 4, pp. 301-312, 2004.

[54] L. S. Collier, C. M. Carlson, S. Ravimohan, A. J. Dupuy, and D. A. Largaespada, "Cancer gene discovery in solid tumours using transposon-based somatic mutagenesis in the mouse," Nature, vol. 436, no. 7048, pp. 272-276, 2005.

[55] S. Rasheed, W. A. Nelson Rees, and E. M. Toth, "Characterization of a newly derived human sarcoma cell line (HT 1080)," Cancer, vol. 33, no. 4, pp. 1027-1033, 1974.

[56] J. Baus, L. Liu, A. D. Heggestad, S. Sanz, and B. S. Fletcher, "Hyperactive transposase mutants of the Sleeping Beauty transposon," Molecular Therapy, vol. 12, no. 6, pp. 1148-1156, 2005.

[57] S. R. Yant, J. Park, Y. Huang, J. G. Mikkelsen, and M. A. Kay, "Mutational analysis of the N-terminal DNA-binding domain of sleeping beauty transposase: critical residues for DNA binding and hyperactivity in mammalian cells," Molecular and Cellular Biology, vol. 24, no. 20, pp. 9239-9247, 2004.

[58] M. Emerman and H. M. Temin, "Genes with promoters in retrovirus vectors can be independently suppressed by an epigenetic mechanism," Cell, vol. 39, no. 3, part 2, pp. 459467, 1984.

[59] S. Hacein-Bey-Abina, C. Von Kalle, M. Schmidt et al., "LMO2associated clonal $\mathrm{T}$ cell proliferation in two patients after gene therapy for SCID-X1," Science, vol. 302, no. 5644, pp. 415-419, 2003.

[60] R. S. Mitchell, B. F. Beitzel, A. R.W. Schroder et al., "Retroviral DNA integration: ASLV, HIV, and MLV show distinct target site preferences," PLoS Biology, vol. 2, no. 8, article e234, 2004.

[61] A. R. W. Schröder, P. Shinn, H. Chen, C. Berry, J. R. Ecker, and F. Bushman, "HIV-1 integration in the human genome favors active genes and local hotspots," Cell, vol. 110, no. 4, pp. 521529, 2002.

[62] M. G. Ott, M. Schmidt, K. Schwarzwaelder et al., "Correction of X-linked chronic granulomatous disease by gene therapy, augmented by insertional activation of MDS1-EVI1, PRDM16 or SETBP1," Nature Medicine, vol. 12, no. 4, pp. 401-409, 2006.

[63] Y. Du, N. A. Jenkins, and N. G. Copeland, "Insertional mutagenesis identifies genes that promote the immortalization of primary bone marrow progenitor cells," Blood, vol. 106, no. 12, pp. 3932-3939, 2005.

[64] A. Narezkina, K. D. Taganov, S. Litwin et al., "Genome-wide analyses of avian sarcoma virus integration sites," Journal of Virology, vol. 78, no. 21, pp. 11656-11663, 2004.

[65] X. Wu, Y. Li, B. Crise, and S. M. Burgess, "Transcription start regions in the human genome are favored targets for MLV integration," Science, vol. 300, no. 5626, pp. 1749-1751, 2003.

[66] S. R. Yant, X. Wu, Y. Huang, B. Garrison, S. M. Burgess, and M. A. Kay, "High-resolution genome-wide mapping of transposon integration in mammals," Molecular and Cellular Biology, vol. 25, no. 6, pp. 2085-2094, 2005.

[67] C. M. Carlson, A. J. Dupuy, S. Fritz, K. J. Roberg-Perez, C. F. Fletcher, and D. A. Largaespada, "Transposon mutagenesis of the mouse germline," Genetics, vol. 165, no. 1, pp. 243-256, 2003.

[68] T. J. Vigdal, C. D. Kaufman, Z. Izsvák, D. F. Voytas, and Z. Ivics, "Common physical properties of DNA affecting target site selection of Sleeping Beauty and other Tc1/mariner transposable elements," Journal of Molecular Biology, vol. 323, no. 3, pp. 441-452, 2002.

[69] C. Baum, O. Kustikova, U. Modlich, Z. Li, and B. Fehse, "Mutagenesis and oncogenesis by chromosomal insertion of gene transfer vectors," Human Gene Therapy, vol. 17, no. 3, pp. 253-263, 2006.

[70] T. W. Chalberg, H. L. Genise, D. Vollrath, and M. P. Calos, " $\varphi \mathrm{C} 31$ integrase confers genomic integration and long-term transgene expression in rat retina," Investigative Ophthalmology and Visual Science, vol. 46, no. 6, pp. 2140-2146, 2005. 

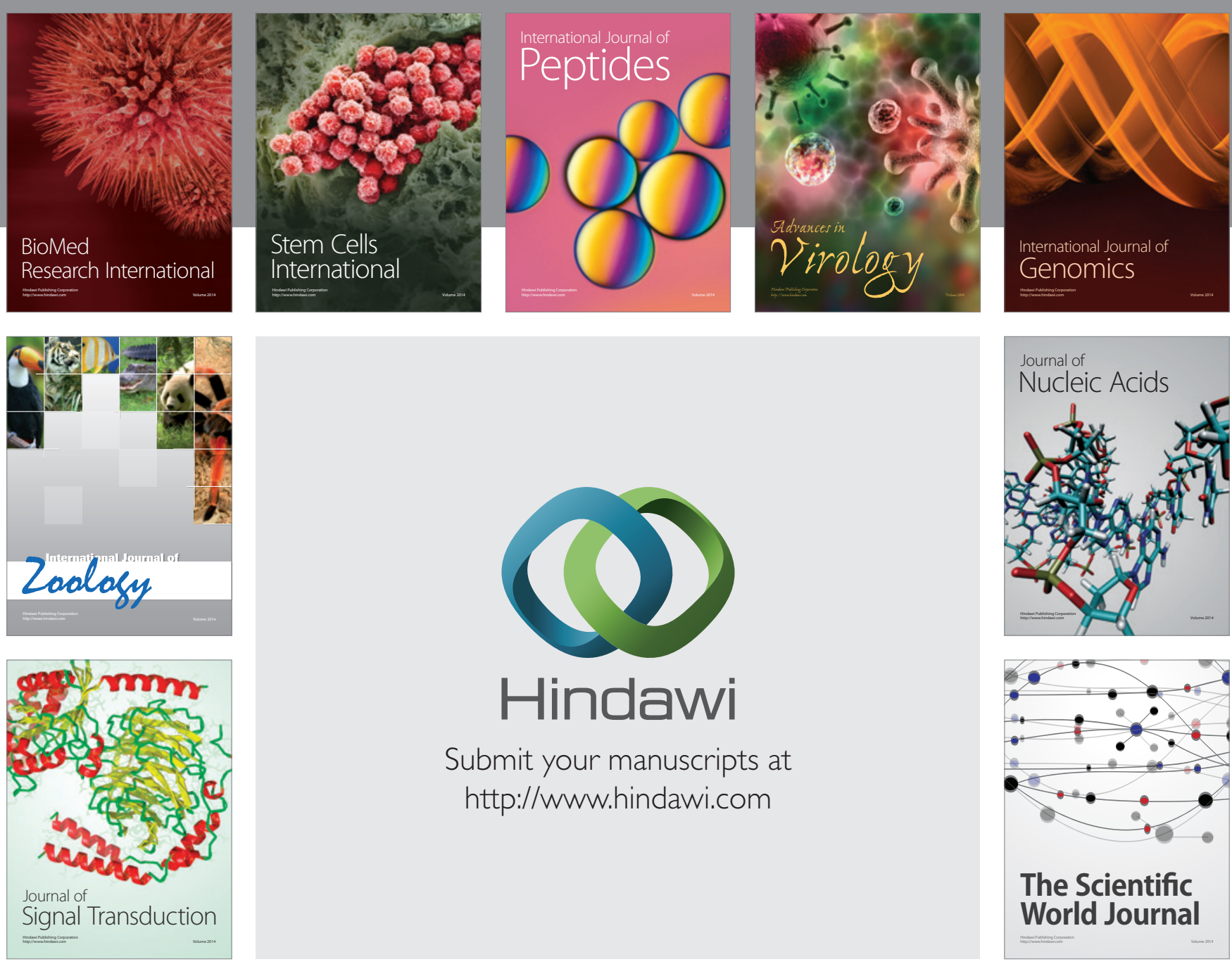

Submit your manuscripts at

http://www.hindawi.com
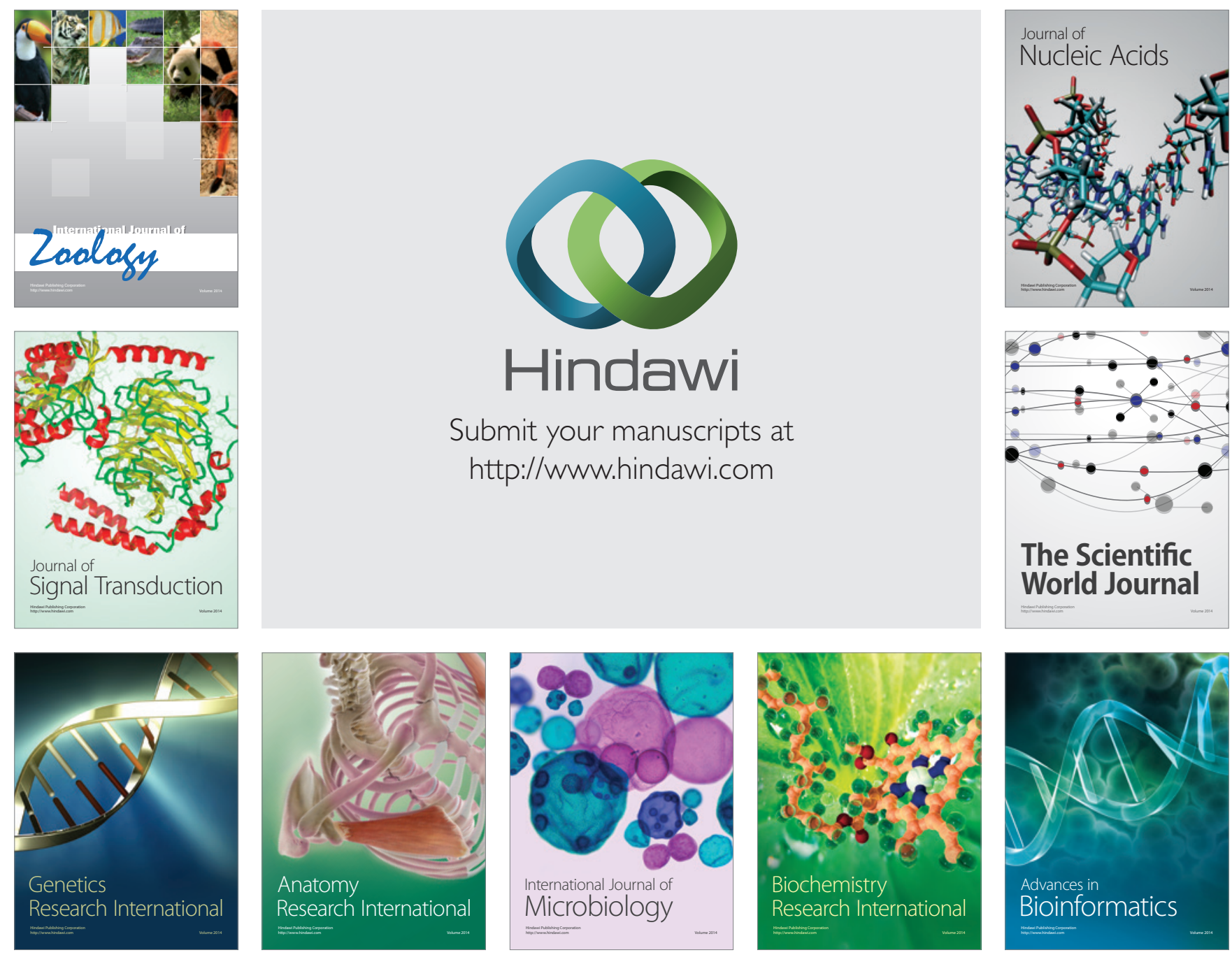

The Scientific World Journal
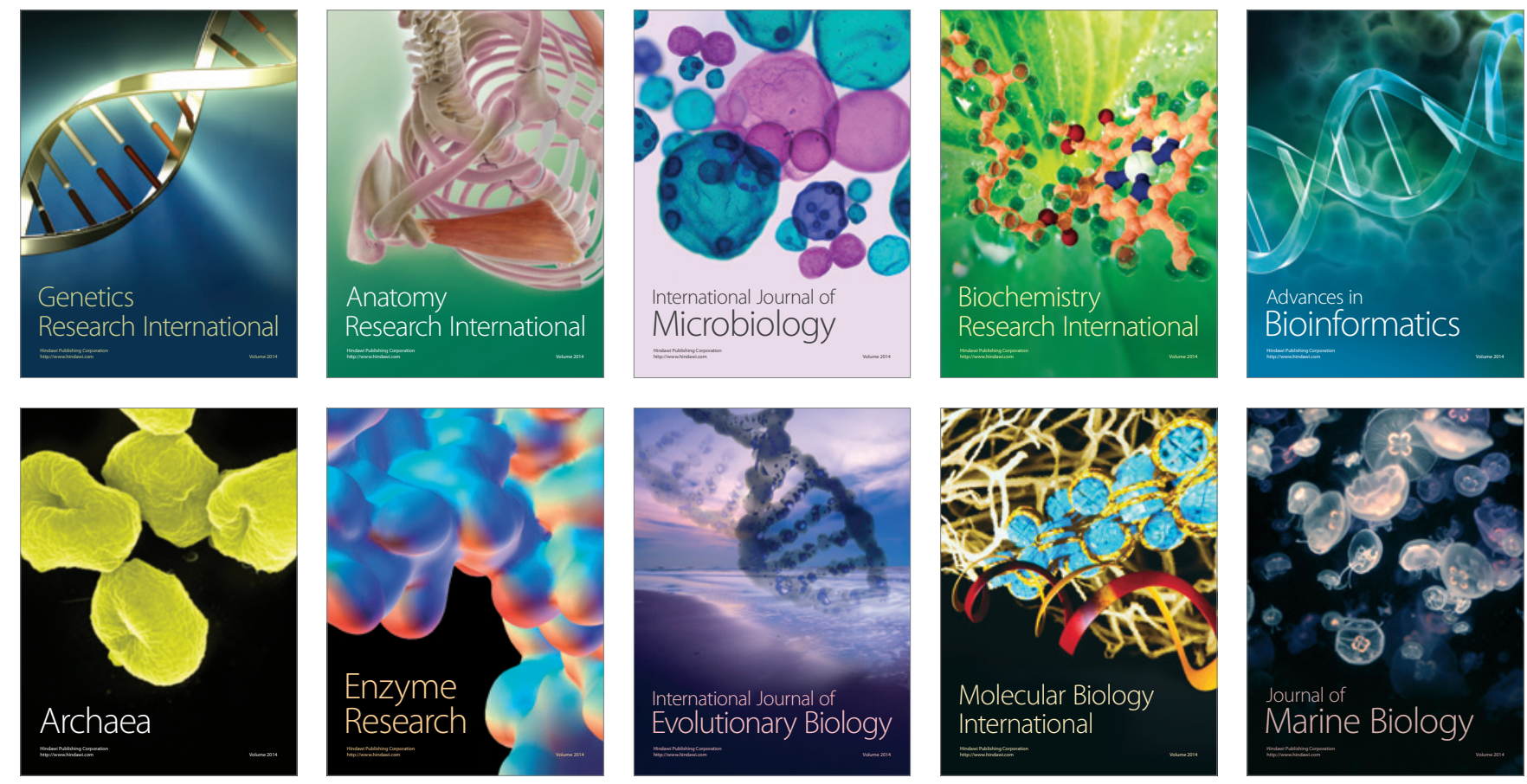